\title{
Testamentary Transfers and the Intent Versus Formalities Debate: The Case for a 'Charitable' Common Ground
}

\author{
By Peter Wendel*
}

\section{INTRODUCTION}

There is a quiet war $^{1}$ being waged in the world of testamentary transfers over how much formality the law should require before giving effect to a time-of-death transfer via a will. ${ }^{2}$ The fight is being played out on two fronts. The first is how much formality the law should require before a document qualifies as a validly executed will. ${ }^{3}$ The second deals with the issue of whether a court should have the power to reform an unambiguous will. ${ }^{4}$

The scholars and estate planning community have split into two camps. In one are the traditionalists. They tend to favor (1) maintaining the prevailing approach to the Wills Act formalities; (2) strict enforcement

* Professor Law, Pepperdine University Caruso School of Law. B.A., 1979, University of Chicago; M.A., 1980, St. Louis University; J.D., 1983 University of Chicago. I am grateful to Professors John H. Langbein, Susan N. Gary, David Horton, Mark L. Ascher, and Jeffrey E. Stake for their helpful comments and criticisms on earlier drafts. Errors or differences that remain do so despite their best efforts. I also thank Alexia Chapman and Jonathan ("Yoni") Horn for their helpful research assistance.

1. A "quiet" war because outside of the world of Wills, Trusts \& Estate professors and estate planners, most people are oblivious to the battle that is being waged. Whether that is relevant to the battle is an interesting question in itself, but that question is beyond the scope of this Article.

2. There are two principal types of wills: an attested will and a holographic will. See UNIF. PROB. CODE § 2-502 (amended 2019). Every jurisdiction recognizes attested wills. See THOMAS P. Gallanis, FAmily PROPERTy LaW: CASES AND Materials ON Wills, Trusts, and Estates 120 (7th ed. 2019). Only about half of the jurisdictions recognize holographic wills. Id. The focus of this Article is attested wills, and thus attested intent. Any reference to a "will" should be assumed to refer to an attested will unless expressly noted otherwise.

3. See infra Parts III, IV, and V; see also John H. Langbein, Substantial Compliance with the Wills Act, 88 HARV. L. REv. 489, 489-91 (1975) [hereinafter Langbein, Substantial Compliance] (highlighting the risks with the traditional "literal compliance" approach and calling on courts to adopt substantial compliance); Emily Sherwin, Clear and Convincing Evidence of Testamentary Intent: The Search for a Compromise Between Formality and Adjudicative Justice, 34 CoNN. L. REV. 453, 473 (2002) (arguing "that judicial leniency toward informal testamentary transactions will undermine the channeling function of statutory formalities, either by eroding the social habit of expressing intent in standard legal form or by making technically compliant wills less reliable.").

4. See infra Part VI; see also John H. Langbein \& Lawrence W. Waggoner, Reformation of Wills on the Ground of Mistake: Change of Direction in American Law?, 130 U. PA. L. REV. 521, 523, 577-79 (1982) [hereinafter Langbein \& Waggoner, Reformation of Wills]. 
of those formalities, even if it means occasionally invalidating an intended will; and (3) permitting courts to construe an ambiguity in a will, but not to reform an unambiguous will. ${ }^{5}$ In the other camp are the intent-oriented advocates. They tend to favor (1) reducing the Wills Act formalities to a minimum; (2) excusing non-compliance with those formalities under the harmless error doctrine; and (3) granting courts the power to reform wills, even unambiguous wills. ${ }^{6}$

While I like to believe I see both sides of the debate, when push comes to shove, I tend to come down on the side of the traditionalists. ${ }^{7}$ Two recent developments, however, gave me cause to reconsider, and change, my position. ${ }^{8}$ To fully appreciate these developments, and why they should cause one to reconsider his or her position, requires a better understanding of the debate.

\section{THE BACKDROP}

In a capitalist system, private property and the right of an owner to transfer his or her property are generally well-accepted. ${ }^{9}$ The right to transfer includes time-of-death transfers. ${ }^{10}$ At time-of-death, if a decedent

5. See infra Parts III.B., and VI.A.; see also John V. Orth, Wills Act Formalities: How Much Compliance is Enough, 43 REAL PROP. TR. \& EsT. L.J. 73, 80-81 (2008) (expressing skepticism that judges should be allowed to re-write wills due to an erosion of Wills Act formalities). It should be noted that while the traditionalists are often depicted as over-focusing on formalities at the expense of testamentary intent, both sides agree testamentary intent is always required for a document to qualify as a validly executed will. See Restatement (ThIRD) OF ProP.: Wills AND DONATIVE TRANSFERS $\S 3.1 \mathrm{cmt}$. g (AM. L. INST. 2003) ("To be a will, the document must be executed by the decedent with testamentary intent ...."); Thomas v. Copenhaver, 365 S.E.2d 760, 762 (Va. 1988) ("To be a valid will, the writing must have been executed with testamentary intent."). One can argue that the debate is more a question of strict compliance versus "loose" or "relaxed" compliance with the formalities.

6. See infra Parts IV., V., and VI.B.; see also, e.g., J. Rodney Johnson, Dispensing with Wills' Act Formalities for Substantively Valid Wills, 18 VA. B. Ass'N J. 10 (1992); Bridget J. Crawford, Wills Formalities in the Twenty-First Century, 2019 WIS. L. REV. 269 (2019).

7. Peter T. Wendel, Wills Act Compliance and the Harmless Error Approach: Flawed Narrative Equals Flawed Analysis?, 95 OR. L. REv. 337, 390-95 (2017) [hereinafter, Wendel, Flawed Narrative].

8. See infra Part VIII.

9. See Ashbel G. Gulliver \& Catherine J. Tilson, Classification of Gratuitous Transfers, 51 YALE L.J. 1, 2 (1941); D. Benjamin Barros, Property and Freedom, 4 N.Y.U. J.L. \& LiBerTY 36 (2009); Thomas W. Merrill, Property and the Right to Exclude, 77 NEB. L. REV. 730, 742-45 (1998) (discussing how the right to transfer both during life and upon death follows logically from the right to exclude); Steven J. Eagle, Private Property, Development and Freedom: On Taking Our Own Advice, 59 S.M.U. L. REV. 345, 345-46 (2006).

10. While the right to transfer property at time-of-death is generally well-accepted, that is not to say that all accept it as a right. No less than the U.S. Supreme Court has acknowledged as much. In Irving Trust v. Day, 314 U.S. 556, 562 (1942), the Supreme Court acknowledged "[n]othing in the Federal Constitution forbids the legislature of a state to limit, condition, or even abolish the power of testamentary disposition over property within its jurisdiction." (citing Mager v. Grima, 49 U.S. 490 
fails to properly express his or her testamentary intent, the property passes through intestacy. ${ }^{11}$ Historically the most common way of opting out of intestacy was to create a will. "Whether a document qualifies as a valid will is a function of two variables: (1) the Wills Act formalities (i.e., the statutory requirements for a valid will), and (2) how strictly the courts require a party to comply with the Wills Act formalities."13

\section{ThE TRADITIONAL APPROACH TO THE WILLS ACT}

\section{A. The Medieval English Approach}

Given that virtually every American jurisdiction traces its Wills Act back to England, ${ }^{14}$ some might be surprised to learn that there was a time when testamentary intent reigned supreme. The power to transfer property at death dates back to Anglo-Saxon times, if not before. ${ }^{15}$ It evolved out

(1850); United States v. Fox, 94 U.S. 315 (1876); United States v. Perkins, 163 U.S. 625 (1896)). See also 1 PAGE ON THE LAW OF WILLS 33.1 (W. Bowe \& D. Parker ed. 1960) [hereinafter PAGE, WILLS]. In Hodel v. Irving, 481 U.S. 704, 716 (1987), the Supreme Court held Section 207 of the Indian Land Consolidation Act unconstitutional, noting that the Act:

[D]estroyed 'one of the most essential sticks in the bundle of rights that are commonly characterized as property - the right to exclude others.' Similarly, the regulation here amounts to virtually the abrogation of the right to pass on a certain type of property - the small undivided interest - to one's heirs. In one form or another, the right to pass on property - to one's family in particular — has been part of the Anglo-American legal system since feudal times.

(quoting Kaiser Aetna v. United States, 444 U.S. 164, 176 (1979) (citing United States v. Perkins, 163 U.S. 625, 627-28 (1896)). See also generally PAGE, WILLS, supra.

11. Intestacy is the state's presumed intent for a decedent who dies without adequately expressing his or her intent. See Susan N. Gary, The Parent-Child Relationship Under Intestacy Statutes, 32 U. MEM. L. REv. 643, 651 (2002).

12. See Kent D. Schenkel, Testamentary Fragmentation and the Diminishing Role of the Will: An Argument for Revival, 41 CREIGHTON L. REV. 155, 156 (2008) (“[E]state planning, which at one time involved not much more than the drafting and execution of a will, is now laden with a multitude of fragmented techniques designed to pass along assets at one's death without the necessity of court supervision." (footnote omitted)); John H. Langbein, The Nonprobate Revolution and the Future of the Law of Succession, 97 HARV. L. REV. 1108, 1108 (1984) [hereinafter Langbein, The Nonprobate Revolution] ("The law of wills and the rules of descent no longer govern succession to most of the property of most decedents.") (emphasis added).

13. Wendel, Flawed Narrative, supra note 7, at 339. See Peter T. Wendel, California Probate Code Section 6110(c)(2): How Big is the Hole in the Dike?, 41 Sw. L. REv. 387, 387-88 (2012) [hereinafter Wendel, California Probate Code Section 6110(c)(2)]; Mark Glover, Minimizing Probate-Error Risk, 49 U. MiCH. J.L. REFORM 335, 341 (2016) [hereinafter, Glover, Minimizing Probate-Error] ("In addition to [the Wills Act] formalities, the conventional law includes the rule of strict compliance." (footnote omitted)).

14. See infra note 42 and accompanying text.

15. See 2 Sir Frederick Pollock \& Frederic William Maitland, The History of 
of local custom, ${ }^{16}$ in particular the custom that recognized that a person's death-bed confession could include a grant of property to the church for the good of one's soul (i.e., to atone for one's sins). ${ }^{17}$ No formalities were

ENGLish LAW BEFore the Time OF EdWARd I 312 (1895) [hereinafter Pollock \& MAITLAND, THE HISTORY OF ENGLISH LAW] (noting that "documents which are often spoken of as Anglo-Saxon wills or testaments" date back to the middle of the ninth century. The rise of the power to devise and the law of wills parallels the rise of private property and the power of one to transfer one's property to whom one pleased.); see also THOMAS E. ATKINSON, HANDBOOK OF THE LAW OF WILLS AND OTHER PRINCIPLES OF SUCCESSION INCLUDING INTESTACY AND DECEDENTS' ESTATES Ch. 1, §§ 2-3 (2nd ed. 1953) [hereinafter ATKINSON, LAW OF WiLLS]; MELVILLE M. BIGELOW, THE LAW OF WILLS FOR STUDENTS 13-14 (1898) [hereinafter BigelOW, THE LAW OF WILLS] (describing the Germanic codes' adoption of wills from Roman jurisprudence); see also Gerry W. Beyer \& Claire G. Hargrove, Digital Wills: Has the Time Come for Wills to Join the Digital Revolution?, 33 OHIO N.U. L. REV. 865, 868 (2007) ("By the eighth century, the 'will' was a familiar concept to English law.") (citing PAGE, WILLS, supra note 10 at $\$ 2.7$ ).

16. See 1 St. GeORge Tucker, Blackstone's Commentaries: With Notes of ReFERENCE, TO THE CONSTITUTION AND LAWS, OF THE FEDERAL GOVERNMENT OF THE UNITED STATES; AND OF the Commonwealth of Virginia Sec. 3, 63 n.1 (1803) [hereinafter Tucker, Blackstone's COMMENTARIES] (acknowledging that English common law was nothing more than general custom that had gained general recognition such that the courts would enforce it). Scholars describe the custom that arose during the Saxon period of letting the decedent dispose of some of his chattel. If the decedent was survived by wife and children, the wife received one-third of the decedent's personal property (the "wife's part"), the children received one-third (the "bairns' part"), and the decedent had the power to dispose of the rest (the "dead's part"). See Pollock \& MaITland, ThE History of ENGLISH LAW, supra note 15, at 314, 318-19, 346, 348-50. If the decedent was survived only by a wife, or only by children, the wife or bairns' share was one-half and "the dead's part" was one-half. $I d$. at 346, 348. If the decedent was not survived by either wife or sons, he could dispose of all personal property. Id. Professor Atkinson theorizes that one can trace the roots of the English "dead's part" to the Roman legitima. See AtKInson, LAW OF Wills, supra note 15, at 9; see also POLLOCK \& MAITLAND, THE HistoRY OF ENGLiSH LAW, supra note 15, at 313 (discussing the transferability of land at time of death and the interaction between law and custom, with custom typically trumping law when the two conflicted):

In the twelfth century it became plain that the Englishman had no power to give freehold land by his will, unless some local custom authorized him to do so. A statute of 1540 ... enabled any person who should 'have' any lands as tenant in fee simple to 'give, dispose, will and devise' the same 'by his last will and testament in writing.' Nevertheless, we find the court's holding - and apparently they are but following a rule which had long been applied to those wills of land that were sanctioned by local custom - that a will of freehold lands is no ambulatory instrument.

(emphasis added) (footnotes omitted); see also id. at 318, 322-29, 347 (discussing (1) the evolution of the "cwide" as a legal instrument that came to be recognized under "Anglo-Saxon folk-law" (emphasis added), and (2) the evolution of the custom — and then law-permitting (and at the same time limiting) a dying individual to transfer a share of his property as he wished ("the new power of testation had come to terms with the ancient rights of the wife, the children and the other kinsfolk.")).

17. Pollock and Maitland note that the Archbishop of York recommended that a priest or deacon who knew he was going to hear a death-bed confession should take witnesses with him so that the decedent's intent could be established despite "the avarice of the kinfolk of the dead [who] contradict what was said by the clergy...." Id. at 316-17, 340. See also TUCKER, BlackstonE's COMMENTARIES, supra note 16, at Sec. 3, 63 n.1 (1803) (acknowledging that English common law evolved out of general custom, eventually gaining the status of authority). 
required. ${ }^{18}$ "[Wills] could be made by a nod of the head or by other sign of assent." 19 Both land and chattels could be devised orally. ${ }^{20}$ By the tenth and eleventh century, however, what had been the death-bed confession had evolved into the written "cwide," ${ }^{21}$ but only as a practical matter to protect one's intent. ${ }^{22}$ No law required it to be in writing. ${ }^{23}$ It was not until the Statute of Wills in 1540 that Parliament imposed the formality that a will must be in writing — but only for wills that devised land. ${ }^{24}$ The Statute of Wills imposed no other formalities (i.e., the will did not need to

18. POllock \& Maitland, The History OF ENGlish Law, supra note 15, at 317 (“And we seem to see that they are as a rule spoken, not written, words ...."). Commenting on the medieval will, Pollock and Maitland wrote: "It is plain that the church has succeeded in reducing the testamentary formalities to a minimum." Id. at 335. The ecclesiastical courts had jurisdiction over the decedent's personal property and thus over the issue of whether the decedent died with a valid will. ATKINSON, LAW OF WILLS, supra note 15, at 15, 18.

19. The history behind the evolution of local customs with respect to the transfer of property at death to law is long and rather obscure. Apparently, it began as an inter vivos transfer on one's death bed (the post-obit gift), but with time became accepted as a time-of-death transfer based on the inter vivos expression of one's testamentary intent. See ATKInSON, LAW OF WILLS, supra note 15, at 1112; C. Douglas Miller, Will Formality, Judicial Formalism, and Legislative Reform: An Examination of the New Uniform Probate Code "Harmless Error" Rule and the Movement Toward Amorphism, 43 Fla. L. REV. 167, 189 (1991); POLlOCK \& MAITLAND, THE HistORY OF ENGLiSH LAW, supra note 15 , at 319, 335 ("The dread of intestacy induces us to hear a nuncupative testament in a few hardly audible words uttered in the last agony, to see a testament in the feeble gesture which responds to the skillful question of the confessor ....").

20. See Pollock \& Mattland, The History of ENGlish LAW, supra note 15, at 314 (discussing the notion that a person could dispose of his property after this death "by written or spoken words ...."). Following the Norman Conquest and the accompanying rise of feudalism, testamentary transfers of land technically were prohibited, but the rise of the use proved a convenient end-run that permitted the continued practice of de facto oral time-of-death transfers of land. See BIGELOW, THE LAW OF WILLS, supra note 15, at 24-25; see also Shelby Myrick Jr., Nuncupative Wills, 7 GA. B.J. 315, 323 (1945) (explaining that "[i]n early English times people were allowed the privilege of making oral wills due to a great amount of illiteracy").

21. Pollock \& MAITlAnd, The History OF ENGlish LAW, supra note 15, at 317-20; Miller, supra note 19 , at $189-90$.

22. See Pollock \& Maitland, The History of English Law, supra note 15, at 319 ("On the whole it seems to us that we have here to deal with a practice which has sprung up among the great, a practice which is ill-defined because it is the outcome of privilegia."); see also ATKINSON, LAW OF WILLS, supra note 15, at 15, 18-19. The written cwide was employed primarily by "very great people, kings, queens, king's sons, bishops, ealdormen, king's thegns." POLLOCK \& MAITLAND, THE HISTORY OF ENGLISH LAW, supra note 15, at 317-18.

23. See Pollock \& MAitland, The History OF ENGlish LAW, supra note 15, at 318-20. While the cwide, in many respects, is the precursor of the written will, it was not required to be in writing. And even when it was, it was "an exceedingly formless instrument." Id. at 317-18, 335-37. See also AtKInson, LAW of Wills, supra note 15, at 15, 19; A.W.B. Simpson, The Will in Medieval England, 78 HARV. L. REV. 1303, 1304 (1965).

24. See Bigelow, The LAW OF WiLls, supra note 15 at 30-31. The Statute of Wills, however, did not apply to all time-of-death transfers of land. If local custom permitted oral testamentary transfers of land, such custom and practice was exempt from the Statute of Wills. See PAGE, WiLLS, supra note 10 , at $\$ 23.5$. Moreover, the Statute of Wills was construed as providing that a will had no ambulatory effect as applied to land acquired after execution of the will. See POLLOCK \& MAITLAND, THE HISTORY OF ENGLISH LAW, supra note 15, at 313. Not until the Statute of Frauds in 1837 was a will accorded ambulatory effect. Id. 
be signed or witnessed), ${ }^{25}$ and chattel could still be devised orally. ${ }^{26}$

The courts were similarly intent oriented. If there was evidence that a party had attempted inter vivos to express his or her time-of-death wishes, the courts bent over backwards in their efforts to ascertain and give effect to that intent. ${ }^{27}$ In his fascinating and exhaustive study of early English probate, Professor Lloyd Bonfield notes the sympathetic approach the courts adopted:

[J]udges in the Prerogative Court [of Canterbury] in the early modern period [the seventeenth century] admitted wills to probate even in instances in which it was doubtful that a will conformed to church court law's own minimal due-execution requirements. They did so in the same way as does the modern judge: they created a narrative of what had actually transpired by sifting through the evidence, and then they surmised as to whether the will-maker intended the document to be his or her last will. If they believed that it did, they ignored the defect and proved the will; if they did not, they proclaimed it a nullity. ${ }^{28}$

As the noted legal historians Pollock and Maitland concluded about the medieval English approach to probate: "[I]ntestacy was rare. It was easy to make a will . ..."29

With time, however, England realized that such a legally open-ended approach to ascertaining testamentary intent involved high costs of administration and opened the probate process to the potential for fraud. ${ }^{30}$ In 1677, Parliament adopted the Statute of Frauds ${ }^{31}$ which substantially ratcheted up the formalities for wills devising land. ${ }^{32}$ The Statute of Frauds imposed the formalities that are now commonly associated with

\footnotetext{
25. ATKINSON, LAW OF WILls, supra note 15 , at 18.

26. See Beyer \& Hargrove, supra note 15, at 870; Miller, supra note 19, at 199.

27. Lloyd Bonfield, Devising, Dying and Dispute: Probate litigation in Early Modern ENGLAND 133 (2017) [hereinafter BONFIELD, DEVISING, DYING AND DisPuTE].

28. Id.

29. Pollock \& Maitland, The History of English Law, supra note 15, at 358.

30. BONFIELD, DEVISING, DYING AND DisPuTE, supra note 27, at 244 ("Surely Parliament's goal must have been to bring order and a greater degree of efficiency to the probate of wills."); see also Myrick, supra note 20, at 323.

31. Statute of Frauds, 29 Car. 2 c. 3 (1677) (Eng.).

32. BONFIELD, DEVISING, DYING AND DisPUTE, supra note 27, at 7.

The Statute of Frauds is arguably the most significant piece of English legislation governing the transmission of property ever adopted, because its guiding principle, novel in the late seventeenth century though commonplace in our own time, was the insistence upon formality in the transfer of property by requiring a written document for particular types of transactions to be binding.
}

Id. (emphasis added) (footnotes omitted). See also id. at 244 ("Surely Parliament's goal must have been to bring order and a greater degree of efficiency to the probate of wills."). 
wills:

[A]ll devises and bequests of any lands or tenements ... shall be in writing and signed by the party so devising the same or by some other person in his presence and by his express directions and shall be attested and subscribed in the presence of the said devisor by three or four credible witnesses or else they shall be utterly void and of none effect. ${ }^{33}$

With respect to devises and bequests of chattels, however, the Statute of Frauds adopted a more informal approach. ${ }^{34}$ While wills devising chattel had to be in writing, they were not subject to any of the other formalities associated with the contemporary will, and the writing requirement did not apply if the will was made in extremis. ${ }^{35}$ The full set of formalities commonly associated with contemporary wills was not extended to wills devising chattel until the English Wills Act of $1837 .{ }^{36}$

Paralleling the imposition of the statutory formalities, slowly but surely, the courts raised the bar on testators, holding them to strict compliance with the statutory Wills Act formalities. ${ }^{37}$ The English legal system found this more structured approach to ascertaining testamentary intent a significant improvement, so much so that it has pretty much held firm with the same formalistic, structured approach to this day. ${ }^{38}$

\section{B. The Traditional American Approach}

The American Revolution was not so much a rebellion against the English legal system as it was a rebellion against a tyrannical Parliament. ${ }^{39}$ Even after the Revolution, the colonists continued to embrace most of their

33. Statute of Frauds, 29 Car. 2 c. 3, § 5 (1677) (Eng.) (edited to reflect modern spelling); see also ATKINSON, LAW OF WILLS, supra note 15, at 20.

34. Historically, wills devising chattel were commonly known as testaments. See ATKINSON, LAW OF WILLS, supra note 15, at 19; Miller, supra note 19, at 188, 197-200.

35. Statute of Frauds, 29 Car. 2 c. 3, § 21 (1677) (Eng.); ATKINSON, LAW OF WiLLS, supra note 15 , at 19 .

36. English Wills Act of 1837, 7 Will. 4 \& 1 Vict., c. 26; ATKINSON, LAW OF WILLS, supra note 15 , at 21 .

37. See Langbein, Substantial Compliance, supra note 3, at 489, 498, 531 (citing J. THAYER, A PRELIMINARY TREATISE ON EVIDENCE 180, 430-31 (1898)).

38. See AtKInSON, LAW OF WiLls, supra note 15, at 22.

39. See ATKINSON, LAW OF WILLS, supra note 15, at 21, 23 (noting the continued influence of English law of succession on the new nation and how the United States "was spared many of the problems of succession which had already been settled by the English."); see also David Villar Patton, The Queen, The Attorney General, and the Modern Charitable Fiduciary: A Historical Perspective on Charitable Enforcement Reform, 11 U. FLA. J.L. \& PUB. POL'Y 131, 145 n.96 (2000) ("The former colonies 'were in the curious predicament of rebelling against the British Crown, and yet being forced by circumstances to continue operating under British laws."') (quoting HowARD S. MILLER, THE LEGAL FOUNDATIONS OF AMERICAN PHILANTHROPY 1776-1844, at 9-10 (1961). 
English legal ancestry. ${ }^{40}$ This was particularly true with respect to the states' Wills Acts. ${ }^{41}$ Virtually every state can trace its Wills Act back to either the English Statute of Frauds of 1677 or the English Wills Act of 1837. ${ }^{42}$ Every Wills Act contains three core formalities: "[t]he will must be (1) in writing, (2) signed by the testator, and (3) witnessed by attesting witnesses." 43 However, no attested Wills Act is that simple. The core formalities have always been accompanied by a plethora of ancillary requirements. ${ }^{44}$ As originally adopted, the English Wills Act of 1837 provided:

$[\mathrm{N}] \mathrm{o}$ will shall be valid unless it shall be in writing, and executed in manner hereinafter mentioned; (that is to say) it shall be signed at the foot or end thereof by the testator, or by some other person in his presence and by his direction; and such signature shall be made or acknowledged by the testator in the presence of two or more witnesses present at the same time, and such witnesses shall attest and shall subscribe the will in the presence of the testator, but no form of attestation shall be necessary. ${ }^{45}$

While scholars can squabble over the exact number of formalities the English Wills Act of 1837 sets forth, the final count easily reaches double digits. ${ }^{46}$ The early American Wills Acts were equally turgid and verbose.

40. See James Lindgren, Abolishing the Attestation Requirement for Wills, 68 N.C. L. REV. 541, 547-50 (1990) (describing the effect of the English Statute of Wills and Statute of Frauds on American law and its continued harshness regarding will formalities); Herbert E. Tucker, David M. Swank \& Thomas G. Hill, Holographic and Nonconforming Wills: Dispensing with Formalities-Part I, 31 CoLO. LAW. 57, 57 (2002) (noting the influence of the English statutes on modern U.S. probate code).

41. See Lawrence W. Waggoner, The UPC Authorizes Notarized Wills, 34 ACTEC J. 83, 83 (2008).

42. Id.; Bruce H. Mann, Formalities and Formalism in the Uniform Probate Code, 142 U. PA. L. Rev. 1033, 1035 (1994); Anne-Marie E. Rhodes, Notarized Wills, 27 QuinNiPIAC Prob. L.J. 419, 419-20 (2014).

43. See Waggoner, supra note 41 , at 83 .

44. See infra note 46 and accompanying text.

45. English Wills Act of 1837, 7 Wm. 4 \& 1 Vict., c. $26 . \S 9$. To the extent some may think 'that was then, this is now,' the current version of the English Wills Act substantively is essentially the same, though stylistically updated a bit. See Waggoner, supra note 41, at n.3 (citing R.E. MEgarRY \& H.W.R. WADE, THE LAW OF REAL PROPERTY II 14-015 (7th ed. Charles Harpum, Stuart Bridge \& Martin Dixon 2008)).

46. For example, here is one possible count of the formalities in the Wills Act:

[N]o will shall be valid unless it shall be (1) in writing and executed in manner hereinafter mentioned; (that is to say) it shall be (2) signed (3) at the foot or end thereof (4)(a) by the testator, or (4)(b) by some other person (4)(b)(i) in his presence and (4)(b)(ii) by his direction; and such signature shall be (5)(a) made or (5)(b) acknowledged by the testator (6) in the presence of (7) two or more witnesses (8) present at the same time, and such witnesses shall (9) attest and (10) subscribe the will (11) in the presence of the testator, but no form of attestation shall be necessary. 
So much for the simple three core formalities.

Whether a document qualifies as a valid will, however, is not just a function of the Wills Act formalities; it is also a function of how strictly the courts interpret and enforce those formalities. ${ }^{47}$ Historically, most courts applied a textualist approach, ${ }^{48}$ giving the statutory formalities their plain meaning. ${ }^{49}$ No attempt was made to take into account the purpose behind the Wills Act or the particular formality. ${ }^{50}$ Either one complied with the plain meaning of the formality in question, or one did not. ${ }^{51}$ The courts focused on compliance, not consequences. ${ }^{52}$ As the Pennsylvania Supreme Court explained recently:

The frustration of decedent's apparent testamentary intent by her own failure to observe the proper formalities may seem at first a harsh result, but it is a result which is required by our Legislature and which this Court may not alter. "The courts must consider that the legislature, having regard to all probable circumstances, has thought it best, and has therefore determined, to run the risk of frustrating the intention sometimes, in preference to the risk of giving effect to or facilitating the formation of spurious wills . . ." Churchill's Estate, supra, $260 \mathrm{~Pa}$. at 101,103 A. at 535. "The strictness with which this section of the Wills Act must be enforced is a matter of legislative mandate. As we said in Brown Estate, supra, [347 Pa. at 246, 32 A.2d at 23]: 'The Wills Act requires signing at the end. The purpose of the Act was to remove all possibility of fraud.... Even if the testamentary intention of this particular testatrix is frustrated, it is much wiser to refrain from weakening the sound and well established mandate of the legislature. Were we to do so, we might in future cases facilitate fraudulent or unauthorized alterations or additions to wills." Coyne Will, $349 \mathrm{~Pa}$. 331, 334, 37 A.2d 509, 510-11 (1944) (emphasis added).

In denying the admission of decedent's will to probate, the auditing judge and the orphans' court en banc obeyed the clear mandate of the

And that count does not include the latent issue that has arisen with respect to whether the testator must sign the will before the witnesses.

47. See Wendel, Flawed Narrative, supra note 7, at 339.

48. Id. at 340 .

49. See Mark Glover, Decoupling the Law of Will-Execution, 88 ST. JOHN's L. REV. 597, 602 (2014) [hereinafter Glover, Decoupling the Law] (explaining that "any error in will-execution invalidates a will, regardless of how minor or technical the formal defect, and despite the court's confidence that the decedent intended the document to constitute a valid will.") (citing Langbein, Substantial Compliance, supra note 3, at 489).

50. Id. at 604. Further, "[c]ritics argue that this formalism conflicts with the cornerstone of the law of wills, which is the principle that testators have broad freedom to dispose of their estates, and that the law's ultimate purpose is to effectuate the testator's intent to exercise this freedom." Id. (footnote omitted).

51. Id. at 601-02.

52. See supra notes $49-50$ and accompanying text. 
Legislature. This Court can do no less. ${ }^{53}$

Under the traditional strict compliance approach, if anyone's intent matters it is that of the legislature, not the testator:

The primary rule governing the interpretation of wills recognizes and endeavors to carry out the intention of the testator. This applies, however, after the will has been admitted to probate, and the rule cannot be invoked in the construction of the statute regulating its execution. In the latter case courts do not consider the intention of the testator, but that of the Legislature. The question is not what did the testator intend to do, but what has he done in the light of the statute..$^{54}$

Justice Scalia would have been pleased..$^{55}$

Bottom line, under the traditional approach, whether a document qualifies as a valid will is a function of (1) a Wills Act with a plethora of formalities, and (2) a judiciary that favors a textual, plain meaning approach to the Act - devoid of any concern for consequences. ${ }^{56}$

\section{THE INTENT APPROACH TO THE WILLS ACT FoRMALITIES}

\section{A. The Traditional Approach's Reign}

This traditional approach to the Wills Act reigned supreme, unchallenged, from the adoption of the English Statute of Fraud in 1677 until the middle of the twentieth century. ${ }^{57}$ In the 1930's, a number of states started to revise their probate codes. ${ }^{58}$ Professor Atkinson, one of the leading Wills, Trusts \& Estates scholars at the time, suggested it might make more sense to have a model probate code that each state could use as the starting point when revising their codes. ${ }^{59}$ The result was the Model

\footnotetext{
53. In re Estate of Proley, 422 A.2d 136, 138-39 (Pa. 1980) (emphasis in the original) (citations omitted).

54. In re Estate of Snyder, 277 N.Y.S. 577, 578 (Surr. Ct. 1935).

55. See generally Jonathan R. Siegel, The Legacy of Justice Scalia and His Textualist Ideal, 85 GEO. WASH. L. REV. 857 (2017) (highlighting Justice Scalia's textualist approach and his ideal that the text is the law). See also Glover, Decoupling the Law, supra note 49, at $602-04$ (providing an example of a court disregarding clear testator intent in ruling a will invalid).

56. See supra notes $48-53$ and accompanying text.

57. See Glover, Decoupling the Law, supra note 49, at 607-08 (explaining the modern trend reform movement's attempt to encapsulate its principles in the 1969 Uniform Probate Code); see also infra notes 77-82 and accompanying text.

58. See generally Thomas E. Atkinson, Old Principles and New Ideas Concerning Probate Court Procedure, 23 J. AM. JuD. Soc. 137 (1939).

59. Thomas E. Atkinson, Wanted -A Model Probate Code, 23 J. AM. JuD. Soc. 183, 189-90 (1940). Professor Atkinson noted that new probate codes were enacted by several states, such as Ohio
} 
Probate Code of $1946 .^{60}$

The Model Probate Code evidences the widespread support for the traditional approach to the Wills Act. Though phrased differently, substantively the Code's Wills Act is almost identical to that of the English Wills Act of 1837. ${ }^{61}$ Moreover, the Model Probate Code accompanied a larger report entitled Problems in Probate Law. ${ }^{62}$ Nowhere in that report, or in either of Professor Atkinson's articles calling for the creation of a model probate code, is there even a hint of criticism or concern with the traditional approach to the Wills Act. ${ }^{63}$

\section{B. The Attack on the Traditional Approach to the Wills Act Formalities}

The first direct attack on the traditional approach to the Wills Act is Professor Mechem's 1948 article entitled Why Not a Modern Wills Act? ${ }^{64}$

in 1931, Florida in 1933, Minnesota in 1935, and Illinois, Kansas, and Michigan in 1939. Id. at 189 n.55. The Real Property, Probate, and Trust Law Section of the American Bar Association took up Professor Atkinson's suggestion, joined forces with the University of Michigan, and the result was the Model Probate Code. See R. G. Patton, Improvement of Probate Statutes-The Model Code, 39 IowA L. REV. 446, 449-51 (1954) (describing the extensive research and drafting process of the 1946 Code involving Professor Atkinson, Professor Simes, the American Bar Association, and the University of Michigan).

60. See Lewis M. Simes \& Paul E. Basye, Model Probate Code, in Problems in Probate LAW 1, at 1-238 (1946).

61. See SiMES \& BASYE, supra note 60, at 81-82. Compared to the English Wills Act of 1837, the model Wills Act does not require either the testator or the witnesses to sign at the end of the will, but otherwise it (a) includes all of the other formalities, and (b) expressly adds the requirement that the testator signify to the witnesses that the document is his or her will. Id. Some sections of the Model Probate Code have Comments explaining the logic behind the section. See, e.g., id. at 83 . There is no comment to Section 47, Wills Execution. Id. at 81-82.

62. See SIMES \& BASYE, supra note 60, at 239-56.

63. The primary focus of the Model Probate Code appears to have been on the judicial organization and procedures of the probate process. See SIMES \& BASYE, supra note 60, at 9. It would be wrong, however, to assume that the drafters did not critically evaluate the then prevailing traditional approach to the Wills Act. As the Chairman of the drafting committee states in the concluding paragraph of the "Presentation of the Report of the Committee on Model Probate Code:"

\footnotetext{
In presenting this Code as the product of five years of preparation and unremitting toil, it is believed that the viewpoint of no important social group has been overlooked and that the content of every important probate statute now on the books has been considered. It would be too much to say that the Code is free from all imperfection. Yet in presenting it to the Section in its final form, it is the belief of your Committee that either as a code complete in itself, or as a fundamental probate law on which to build a larger legislative superstructure, it can be recommended without qualification to the legislative authorities of any jurisdiction in which probate reform is sought.
}

SIMES \& BASYE, supra note 60, at 8 (emphasis added). When the Model Probate Code was drafted in the mid-1940's, there appears to have been a general consensus that the traditional approach to the Wills Act formalities was the best approach.

64. See Philip Mechem, Why Not a Modern Wills Act?, 33 IowA L. REV. 501 (1948). One can 
While acknowledging the good work done by the drafters of the Model Probate Code generally, Professor Mechem took them to task for their poor effort with respect to the model Wills Act:

A reviewer [of the Model Probate Code] speaks of the "fairness, the imagination, the resourcefulness and the restrained audacity of the draftsmen." That is strong talk but probably few would cavil at it. The writer, however, is a little disturbed by one portion of the Code, small but of great importance, namely, the provisions relating to the execution, revocation, and operation of wills. The draftsmen here seem to the writer to have displayed anything but imagination, resourcefulness, or audacity, restrained or otherwise. On the contrary, these provisions seem to him almost incredibly reactionary, unimaginative, and timid. The Statute of Frauds was passed in 1677. One is asked to think either that that famous enactment was so perfect as to need no improvement or that the framers of the Code have learned nothing from the experience of the intervening 270 years. $^{65}$

Professor Mechem then took aim at the Wills Act formalities: "the philosophy should be to impose only such requirements as seem so unmistakably essential to a safe will-making process as to justify running the known risk of defeating meritorious wills through failure of testators to know or comply with the requirements." ${ }^{\circ 6}$ While acknowledging the benefits of the core formalities, Professor Mechem questioned the value of most of the ancillary formalities. ${ }^{67}$ His proposed model Wills Act, ${ }^{68}$

argue that the seminal 1941 law review article by Gulliver \& Tilson, Classification of Gratuitous Transfers, supra note 9, constitutes the first attack on the traditional approach to the Wills Act, and to a degree that would be accurate. As part of the article's analysis of gratuitous transfers generally, it examines the Wills Act formalities and questions the value of several of the ancillary formalities. Id. at 5-14. The article does not, however, propose any specific revisions to the Wills Act. It focuses on the legal consequences of classifying a gratuitous transfer as one type or another (will, gift, trust, or contract) and advocates for a flexible approach to classifying gratuitous transfers to ensure that the transfer is given effect where the functions underlying the doctrinal formalities and the equities involved justify it, even if the traditional doctrinal formalities do not. Id. at 17-18. Professor Mechem's article, in contrast, directly attacks the traditional approach and offers a different approach both philosophically and doctrinally. See Mechem, supra.

65. Mechem, supra note 64, at 501 (footnote omitted).

66. Id. at 503 .

67. Id. at 503-07.

68. Mechem's assessment of each formality is implicitly reflected in his proposed Wills Act based on his minimalistic approach:

$\S 46$. Execution. All wills, other than nuncupative or holographic wills, shall be in writing, signed by the testator and by two or more attesting witnesses, and shall be executed as follows:

(a) Testator. Testator's signature may be made by himself, or by someone for him in his presence and by his direction, and his signature shall either be made, or exhibited and acknowledged by him, in the presence of each of the witnesses, though not necessarily of 
which is markedly different from the paradigm traditional Wills Act (i.e., the English Wills Act of 1837 and/or the Model Probate Code of 1946), eliminates many of the ancillary formalities: neither the testator nor the witnesses need sign at the end of the will ${ }^{69}$ the witnesses need not be present at the same time when the testator signs or acknowledges $;^{70}$ the witnesses need not be present at the same time when they attest the will ${ }^{71}$ the testator need not be present when either of the witnesses attest the will $;{ }^{72}$ and the testator need not publish the will. ${ }^{73}$ The gauntlet had been thrown down. ${ }^{74}$

When viewed with the benefit of history, maybe the most surprising aspect of Professor Mechem's article is the academic community's scholarly response to it: there was none. ${ }^{75}$ In the two decades following its publication not a single law review article commented on his minimalist approach to the Wills Act formalities. ${ }^{76}$ In 1962, however, the American Bar Association joined forces with the National Conference on Uniform Laws to revise the Model Probate Code of $1946 .{ }^{77}$ The result was the

both at the same time.

(b) Witnesses. The witnesses need not sign in the presence of the testator nor of each other, but if either or both of them do not sign in the presence of the testator the one or ones not so signing shall exhibit his or their signature or signatures to the testator and acknowledge the same.

(c) Publication. No formal publication nor request to the witnesses to sign shall be necessary nor shall it be necessary that the witnesses know the contents of the instrument, or that it is a will, but before the will shall be admitted to probate, the trier of fact must be satisfied that testator intended the instrument to take effect and that the witnesses knew from the statements or conduct of the testator that he intended the instrument to take effect and wished them to witness it.

Id. at $507-08$.

69. Id.

70. Id. at 508 .

71. Id.

72. $I d$.

73. Id.

74. Professor Mechem explained, "[h]ad the framers of the Code been able to produce a blue print for such a procedure it would indeed have marked an epochal advance in the history of probate practice, far beyond anything they have actually accomplished, however careful and praiseworthy their product may be deemed." Id. at 521 .

75. Between 1948, when Professor Mechem's article was published, and 1969, when the National Law Commission published the Uniform Probate Code with its model Wills Act, there was only one cite to Professor Mechem's article - and it had to do with the doctrine of ademption, not his attack on the traditional Wills Act formalities. See Ademption and the Testator's Intent, 74 HARV. L. REV. 741, 751 n.58 (1961).

76. See supra note 75 and accompanying text.

77. See Lawrence H. Averill Jr., An Eclectic History and Analysis of the 1990 Uniform Probate Code, 55 ALB. L. ReV. 891, 895-96 (1992). 
Uniform Probate Code ("UPC") of 1969. ${ }^{78}$ The official Comment to the UPC's Wills Act, Article 2, Part 5, provides in pertinent part: "[E]xecution must be kept simple .... To this end, ... formalities for a written and attested will are kept to a minimum ...."79

If one were to create a spectrum, with the English Wills Act of 1837 at one end and Professor Mechem's proposed Wills Act at the other, the UPC's Wills Act is much closer to Professor Mechem's proposed Wills Act: ${ }^{80}$ neither the testator nor the witnesses need sign at the end of will; the witnesses need not be present at the same time when the testator signs or acknowledges; the witnesses need not be present at the same time when they attest the will; the testator need not be present when either of the witnesses attest the will; and the testator need not publish the will. ${ }^{81}$ Although the UPC's drafting committee never expressly acknowledged Professor Mechem's article, the drafting committee fully embraced and implemented his minimalist approach. ${ }^{82}$

If the goal of the 1969 UPC's Wills Act was to draw attention to the issue of how many formalities a jurisdiction should have in its Wills Act, and to reduce the number of formalities, it has succeeded. After the Uniform Law Revisions Commission promulgated UPC Section 2-502 (the UPC's proposed Wills Act), almost every state undertook a similar process: critically re-assessing its Wills Act formalities to see if some of

78. After six drafts, the two committees finally agreed upon the Uniform Probate Code, the official text of which was approved by the National Conference on Uniform Laws and the House of Delegates of the American Bar Association in 1969. Id. at 896.

79. See UnIF. Prob. CodE, art. 2, pt. 5 General Comment (amended 2019); Mechem, supra note 64 , at $507-08$.

80. Section 2-502 [Execution]

Except as provided for holographic wills, ... every will shall be in writing signed by the testator or in the testator's name by some other person in the testator's presence and by his direction, and shall be signed by at least 2 persons each of whom witnessed either the signing or the testator's acknowledgment of the signature or of the will.

UNIF. PROB. CODE § 2-502 (amended 2019).

81. See id. Moreover, the UPC's Wills Act goes further: there is no requirement that if a witness does not sign in the testator's presence that the witness must "exhibit his or their signature or signatures to the testator and acknowledge the same." Mechem, supra note 64, at 508. There is no requirement "that the witnesses knew from the statements or conduct of the testator that he intended the instrument to take effect and wished them to witness it." Id. The UPC also "authorizes holographic wills, and it reduces the number of formal requirements for both attested and holographic wills below the minimum levels customary in previous American Wills Acts." See Langbein, Substantial Compliance, supra note 3 , at 510

82. Notably, the general comment to the Wills section of the UPC explains: "If the will is to be restored to its role as the major instrument for disposition of wealth at death, its execution must be kept simple. The basic intent of these sections is to validate the will whenever possible." See UNIF. PROB. CODE, art. 2, pt. 5 General Comment (amended 2019). 
the ancillary formalities could be eliminated. ${ }^{83}$ The end result shows the impact of the 1969 UPC Wills Act. If one were to create a spectrum, with the traditional Wills Act patterned on the English Wills Act of 1837 on one end, and the UPC Wills Act, Section 2-502, on the other end, the states are spread all across the spectrum. A little over a dozen states have retained most of the formalities embodied in traditional Wills Act. ${ }^{84} \mathrm{~A}$ little over a dozen states have adopted the 1969 UPC's Wills Act, Section $2-502 .{ }^{85}$ The rest of the states, a slight majority, have followed the UPC's lead and revised their Wills Act to significantly reduce the number of ancillary formalities, but their formalities differ from the UPC formalities. ${ }^{86}$

\section{See infra notes $84-85$.}

84. ARK. Code AnN. § 28-25-103 (West, Westlaw through 2020 1st Sess.); Fla. STAt. AnN. § 732.502 (West, Westlaw through 2020 2nd Sess.); IND. CODE ANN. § 29-1-5-3 (West, Westlaw through 2020 2nd Sess.); IOWA CODE ANN. § 633.279 (West, Westlaw through 2020 Sess.); KAN. StAT. ANN. § 59-606 (2018); Ky. Rev. Stat. ANN. § 394.040 (West, Westlaw through 2020 Sess.); LA. CIV. CodE ANN. art. 1577 (Westlaw through 2019 Sess.) (the Louisiana notarial testament is unique, not based on English legal precedent, but in terms of formalities, it is closer to the English Wills Act of 1837 than the Uniform Probate Code section 2-502); N.M. STAT. ANN. § 45-2-502 (West, Westlaw through 2020 2nd Sess.); 20 PA. STAT. AND CONS. STAT. $\$ 2502$ (West, Westlaw through 2020 Act 78); 33 R.I. GEN. LAWS ANN. § 33-5-5 (West, Westlaw through Ch. 79 of 2020 2nd Sess.); Tenn. Code AnN. § 32-1-104 (West, Westlaw through 2020 2nd Sess.); Vt. STAT. ANN. tit. 14, § 5 (West, Westlaw through Act 150 of 2019-2020 Sess.); VA. CODE ANN. § 64.2-403 (West, Westlaw through 2020 Sess.); W. VA. CODE ANN. § 41-1-3 (West, Westlaw through 2020 Sess.).

85. Ala. Code $§ 43-8-131$ (Westlaw through 2020 Act 206); HAW. ReV. STAT. AnN. § 560:2502 (West, Westlaw through 2020 Act 15); IDAHO CODE ANN. § 15-2-502 (West, Westlaw through 2020 2nd Sess.); Me. Rev. Stat. AnN. tit. 18-C, § 2-502 (Westlaw through 2019 2nd Sess.); Mass. GEN. Laws ANN. ch. 190B, § 2-502 (West, Westlaw through Ch. 176 of 2020 2nd Sess.); Mich. COMP. Laws ANN. § 700.2502 (West, Westlaw through P.A.2020, No. 164, 2020 Sess.); MinN. STAT. ANN. § 524.2-502 (West, Westlaw through 2020 Sess.); MonT. CodE ANN. § 72-2-522 (West, Westlaw through 2019 Sess.); NeB. Rev. Stat. ANN. § 30-2327 (West, Westlaw through 2020 2nd Sess.); N.J. StaT. ANN. § 3B:3-2 (West, Westlaw through L.2020, c. 86); N.D. CENT. CODE ANN. § 30.1-08-02 (West, Westlaw through 2019 Sess.); OR. Rev. STAT. ANN. 112.235 (West, Westlaw through 2020 Sess.); S.C. CODE ANN. § 62-2-502 (Westlaw through 2020 Act 142); UTAH CODE ANN. $\S 75-2-502$ (West, Westlaw through 2020 6th Sess.). But see George Holmes, Comment, Testamentary Formalism in Louisiana: Curing Notarial Will Defects Through a Likelihood-of-Fraud Analysis, 75 LA. L. REV. 511, 520 (2014) (asserting that "roughly 20 states" have adopted "some form" of UPC Section 2-502).

86. ARiZ. Rev. Stat. AnN. § 14-2502 (Westlaw through 2020 2nd Sess.); CAL. Prob. CodE $\S$ 6110 (West, Westlaw through Ch. 372 of 2020 Sess.); Colo. Rev. STAT. AnN. § 15-11-502 (West, Westlaw through 2020 Sess.); ConN. GEN. StAT. ANN. § 45a-251 (West, Westlaw through 2020 Sess.); Del. Code ANN. tit. 12, § 202 (West, Westlaw through Ch. 292 of 2019-2020 Sess.); D.C. Code ANN. § 18-103 (West, Westlaw through Aug. 14, 2020); GA. CODE ANN. § 53-4-20 (West, Westlaw through 2020 Act 545); 755 ILl. COMP. STAT. ANN. 5 \$ 5/4-3 (West, Westlaw through P.A. 101-651, 2020); MD. CODE ANN., EST. \& TRUSTs § 4-102 (West, Westlaw through 2020 Sess.); Miss. Code AnN. § 91-5-1 (West, Westlaw through Sept. 20, 2020); Mo. ANN. STAT. § 474.320 (West, Westlaw through West ID No. 28 of 2020 Sess.); Nev. Rev. Stat. AnN. § 133.040 (West, Westlaw through 2020 32nd Sess.); N.H. REV. STAT. ANN. § 551:2 (Westlaw through Ch. 39 of 2020 Sess.); N.Y. Est. POWERS \& TRUSTS LAW § 3-2.1 (McKinney, Westlaw through Ch. 199 of L.2020); N.C. GEN. STAT. ANN. § 31-3.3 (West, Westlaw through S.L. 2020-74 of 2020 Sess.); OHIO REv. CodE 
Although the jurisdictions could not agree on which formalities should be eliminated and which should be retained (other than the core formalities), ${ }^{87}$ the fact that the overwhelming majority of jurisdictions have revised their Wills Act to reduce significantly the number of ancillary formalities shows that at the macro level, many traditionalists concluded that the traditional Wills Act modeled on the English Wills Act of 1837 was outdated and in need of revision. ${ }^{88}$ Whichever formalities a jurisdiction retained, however, it is safe to assume the formality was retained because the jurisdiction's law revision commission determined that the formality serves an important function. Inasmuch as each retained formality serves an important function, it is logical to assume that the courts should insist on strict compliance with each retained formality. No doubt that is the assumption and logic many traditionalists, and the UPC, initially adopted ${ }^{89}$ and that reasoning helps to explain the traditionalists more tepid response to the more recent proposals by the intent-oriented activists. $^{90}$

ANN. $§ 2107.03$ (West, Westlaw through File 48 of 2019-2020 Sess.); OKLA. STAT. ANN. tit. 84, § 55 (West, Westlaw through 2020 2nd Sess.); TEX. Est. CoDE ANN. § 251.051 (West, Westlaw through 2019 Sess.); WASH. REV. CODE ANN. § 11.12.020 (West, Westlaw through 2020 Sess.); WIS. STAT. ANN. § 853.03 (West, Westlaw through 2019 Act 186); WYo. STAT. ANN. § 2-6-114 (West, Westlaw through 2020 Budget Sess.). See Holmes, supra note 85, at 520-21.

87. While the three core requirements remain in every state's Wills Act, there is greater variance today between and among the States' approaches to the ancillary formalities than ever before. See Roger W. Andersen, The Influence of the Uniform Probate Code in Nonadopting States, 8 U. PUGET Sound L. REV. 599, 601-02 (1985). Many states took a piecemeal approach to the UPC, adopting parts of the Wills Act and other sections of the Code with modifications. Id. at 600-02. Further, regarding the UPC's Wills Act, Article II has been described as having a "broad but thin appeal" in that almost every section had been followed in some states, but no single section could garner the support of more than some states. Id. at 602 . At one end of the spectrum, virtually every state has agreed with the Uniform Probate Code that the traditional formality that the testator must publish his or her will no longer makes sense and has been abolished. See Diane J. Klein, How to Do Things with Wills, 32 WhitTIER L. REV. 455, 466 n.65 (2011). At the other end of the spectrum, however, very few states have agreed with the Uniform Probate Code that the testator need not sign or acknowledge the will in the presence of two witnesses present at the same time. See Lindgren, supra note 40, at 549, 571. Many states refused to abolish this requirement because of its utility in proving the validity of a will. $I d$. As for the other formalities the Uniform Probate Code eliminated, the results are more mixed, with some states adopting the Uniform Probate Code's position, and some states sticking with the traditional approach. See generally Andersen, supra.

88. No doubt the traditionalists' voices were present in the debates within each state over (a) which formalities should be eliminated, and (b) which should be retained; and their voices help to explain the split in the jurisdictions. See supra notes $84-86$.

89. See James Lindgren, The Fall of Formalism, 55 ALB. L. REV. 1009, 1011 (1992) (describing the immediate era after the adoption of UPC Section 2-502, Professor Lindgren acknowledges that "[t]he approach of the Uniform Probate Code from 1969 until 1990 was to reduce will formalities, but to require strict compliance with those formalities."); see also Holmes, supra note 85, at 520.

90. See infra notes 102-03 and accompanying text. 


\section{THE ATtACK ON THE StRICT COMPLIANCE JUdiCIAL APPROACH}

In 1975, Professor John Langbein opened up a second front in the attack on the traditional approach to how much formality the law should require before giving effect to testamentary intent. ${ }^{91}$ In his now landmark article, Substantial Compliance with the Wills Act, ${ }^{92}$ Professor Langbein criticized the courts for requiring "literal compliance" with the Wills Act formalities: ${ }^{93}$

The law of wills is notorious for its harsh and relentless formalism. The Wills Act prescribes a particular set of formalities for executing one's testament. The most minute defect in formal compliance is held to void the will, no matter how abundant the evidence that the defect was inconsequential. Probate courts do not speak of harmless error in the execution of wills .... [O]nce a formal defect is found, Anglo-American courts have been unanimous in concluding that the attempted will fails.

$\ldots[\mathrm{T}] \mathrm{he}$ insistent formalism of the law of wills is mistaken and needless. ${ }^{94}$

Professor Langbein's article pivoted the formality versus intent debate from a statutory issue to a judicial issue; from how many formalities the Wills Act should have to how the formalities should be construed and applied. ${ }^{95}$ Professor Langbein argued that the traditional, "literal" approach needs to give way to a more "purposive" approach. ${ }^{96}$

Professor Langbein's view on what constitutes a more purposive approach has changed over time. Initially he argued for a substantial compliance approach - but one that is holistic, rather than formality based. If a will failed under strict compliance, the courts should subject the document "to a further inquiry: does the noncomplying document express the decedent's testamentary intent, and does its form sufficiently approximate Wills Act formality to enable the court to conclude that it

\footnotetext{
91. See Langbein, Substantial Compliance, supra note 3, at 489.

92. Id.

93. Id. Professor Langbein shifted to the more commonly used "strict compliance" term to describe the traditional judicial approach to Wills Act compliance in his subsequent article on the issue. See generally John H. Langbein, Excusing Harmless Errors in the Execution of Wills: A Report on Australia's Tranquil Revolution in Probate Law, 87 Colum. L. REV. 1 (1987) [hereinafter Langbein, Harmless Errors].

94. Langbein, Substantial Compliance, supra note 3, at 489.

95. Professor Langbein highlighted the peculiarity of "judicial insistence that any defect in complying with [the formalities] automatically and inevitably voids the will" when the judiciary shows more deference to noncompliant Statute of Frauds transactions. Id. at 498-99.

96. Langbein argued on this point that "[b]y substituting a purposive analysis for a formal one, the substantial compliance doctrine would actually decrease litigation about the formalities." Id. at
} 526. 
serves the purposes of the Wills Act?" 97 Just over a decade later, Professor Langbein revised his view, rejecting substantial compliance (which deems compliance despite a flaw in the execution ceremony) in favor of a harmless error approach (which empowers the court to validate a will by excusing noncompliance).$^{98}$ So long as there is clear and convincing evidence that the decedent intended the document to constitute his or her will, the court is empowered to excuse any defect in the execution of the will. ${ }^{99}$ The UPC has adopted Professor Langbein's harmless error approach. ${ }^{100}$ Empowering courts to probate wills that fail to comply with the Wills Act formalities increases the courts' ability to give effect to decedents' testamentary wishes. ${ }^{101}$

The attack on the traditional strict compliance judicial approach has not been as successful as the attack on the statutory Wills Act formalities. Thirty years after the adoption of Section 2-503 to the Uniform Probate Code, only eleven states have revised their Probate Code to include the harmless error doctrine ${ }^{102}$ - and several of them have adopted a limited form of the harmless error doctrine that limits the formalities to which it can be applied (e.g., prohibiting its application to the signature requirement). ${ }^{103}$ Similar to the statutory approach to the Wills Act

\footnotetext{
97. Id. at 489 .

98. Langbein, Harmless Errors, supra note 93, at 6-7.

99. Id.

100. The Uniform Probate Code provides in pertinent part:
}

\begin{abstract}
Although a document or writing added upon a document was not executed in compliance with Section 2-502 [will execution requirements], the document or writing is treated as if it had been executed in compliance with [the execution requirements] if the proponent of the document or writing establishes by clear and convincing evidence that the decedent intended the document or writing to constitute ... the decedent's will.
\end{abstract}

UNIF. PROB. CODE § 2-503 (amended 2019).

101. See infra note 116 and accompanying text.

102. See CAL. Prob. CodE $\S 6110$ (c)(2) (West, Westlaw through Ch. 372 of 2020 Sess.); Colo. Rev. Stat. AnN. § 15-11-503 (West, Westlaw through 2020 Sess.); HaW. Rev. Stat. AnN. § 560:2503 (West, Westlaw through 2020 Act 15); Mich. Comp. LaWs ANN. § 700.2503 (West, Westlaw through P.A.2020, No. 164, 2020 Sess.); MONT. CODE ANN. § 72-2-523 (West, Westlaw through the 2019 Sess.); N.J. Stat. ANN. § 3B:3-3 (West, Westlaw through L.2020, c. 86); OHIO Rev. CodE ANN. $\S 2107.24$ (West, Westlaw through File 48 of 2019-2020 Sess.); OR. ReV. STAT. ANN. § 112.238 (West, Westlaw through 2020 Sess.); S.D. CodIFIED LAws § 29A-2-503 (Westlaw through 2020 Sess.); UtAh CODE ANN. § 75-2-503 (West, Westlaw through 2020 6th Sess.); VA. CODE ANN. § 64.2404 (West, Westlaw through 2020 Sess.).

103. See CAL. Prob. Code $\S 6110$ (c)(2) (West, Westlaw through Ch. 372 of 2020 Sess.) (limiting the harmless error doctrine to execution defects related to the witnessing requirements and not permitting it to be applied to defects related to the signature requirement); COLO. REV. STAT. ANN. § 15-11-503(2) (West, Westlaw through 2020 Sess.) (limiting Colorado's harmless error doctrine to documents "signed or acknowledged by the decedent as his or her will or if it is established by clear 
formalities, there is greater variance between and among the states' judicial approach to the Wills Act formalities than ever before.

\section{THE POWER TO REFORM AN UNAMBIGUOUS WILL}

\section{A. The Traditional Approach: Construe Only}

Lastly, an issue that has long troubled the courts is, assuming a validly executed will, how open to extrinsic evidence should the courts be to help give effect to testator's intent. Under the older traditional approach, the courts applied the plain meaning rule and would admit extrinsic evidence only if there was a latent ambiguity in the will. ${ }^{104}$ Most courts today, however, admit extrinsic evidence to help the court construe the will anytime there is an ambiguity-whether it be a latent or patent ambiguity. ${ }^{105}$ While courts have become increasingly open to extrinsic evidence to help construe an ambiguity in the will, most courts have attempted to hold the line on re-writing a will. These courts still follow the traditional view that it is one thing to construe an ambiguity in a will; it is another to re-write an unambiguous will. ${ }^{106}$ The reasons given for drawing that line resonate with those who favor the more traditional approach to testamentary formalities:

and convincing evidence that the decedent erroneously signed a document intended to be the will of the decedent's spouse."); VA. CODE ANN. § 64.2-404(B) (West, Westlaw through 2020 Sess.) (providing that Virginia's harmless error doctrine "may not be used to excuse compliance with any requirement for a testator's signature," except in very limited, statutorily defined circumstances).

104. See Ann E. Breuer, Note, Pellegrini v. Breitenbach and Courts' Reluctant Power to Reform Innocent Mistakes in Wills, 26 QUINNIPIAC PROB. L.J. 46, 51-52 (2012). Under this approach, the courts would not admit extrinsic evidence if there was a patent ambiguity, and in analyzing whether there was an ambiguity the courts applied the plain meaning rule - the words in the will should be given their plain and ordinary meaning. E.g., Winet v. Price, 4 Cal. App. 4th 1159, 1165 (1992); Pihlajamaa v. Kaihlan (In re Estate of Kaila), 114 Cal. Rptr. 2d 865, 872-74 (Ct. App. 2001).

105. See Breuer, supra note 104, at 52. And in determining whether the will contains an ambiguity, many courts have rejected the plain meaning rule. See generally Andrea W. Cornelison, Dead Man Talking: Are Courts Ready to Listen? The Erosion of the Plain Meaning Rule, 35 REAL PROP. PROB \& TR. J. 811 (2001) (discussing the plain meaning rule and analyzing the ways courts have begun to reject it). Uniform Probate Code $\$ 2-502(\mathrm{c})$ permits extrinsic evidence to establish testamentary intent, thereby abandoning the hoary "four-corners" rule that required the testator's intent to be determined within the four corners of the document - a rule that, in any event, was more a statement of an ideal. UNIF. PROB. CODE § 2-502(c) (amended 2019). Moreover, in analyzing whether the will contains an ambiguity, the courts should take into consideration the circumstances surrounding the testator at time of execution and analyze the wording in the will in light of those circumstances in assessing whether the will contains an ambiguity. Cornelison, supra at 819-24, 828-32.

106. Cornelison, supra note 105, at 817 ("The no-reformation rule says that courts shall not change the language of a will or give effect to language not contained in a will because 'the objection arises that the language to be supplied was not written, signed, and attested as required by the Wills Act.") (quoting Langbein \& Waggoner, Reformation of Wills, supra note 4, at 528); see also Mark Glover, A Taxonomy of Testamentary Intent, 23 GEO. MASON L. REV. 569, 601-02 (2016) [hereinafter Glover, A Taxonomy of Intent]. 
[T]he reformation of a will, which would dispose of estate property based on unattested testamentary language, would violate the Statute of Wills. Strong policy reasons also militate against the requested reformation. To allow for reformation in this case would open the floodgates of litigation and lead to untold confusion in the probate of wills. It would essentially invite disgruntled individuals excluded from a will to demonstrate extrinsic evidence of the decedent's "intent" to include them. The number of groundless will contests could soar. We disagree that employing "full, clear and decisive proof" as the standard for reformation of wills would suffice to remedy such problems . . . . Judicial resources are simply too scarce to squander on such consequences. ${ }^{107}$

\section{B. Modern Trend: Power to Reform an Unambiguous Will}

The testamentary intent movement takes issue with the traditional distinction between construing and re-writing a will. The intent approach believes testamentary intent should be given effect anytime there is adequate evidence of that intent. ${ }^{108}$ If clear and convincing evidence is sufficient to validate an improperly executed will, clear and convincing evidence should be sufficient to reform a poorly drafted will. ${ }^{109}$ Professor Langbein made that point near the end of his article proposing the harmless error approach for mistakes in the execution of a will:

The development of a statutory remedy to cure mistakes in complying with execution formalities invites consideration of the parallel... problem of mistakes in content. When a typist drops a paragraph, or a lawyer misdescribes a devisee, the law should be prepared to correct the error if the error can be proved according to the same clear and convincing standard of proof that applies when such mistakes arise in the law of will substitutes. In the law of wills, both the traditional refusal to excuse innocuous execution errors and the traditional refusal to correct obvious mistakes in content, result from the same theoretical excessovervaluing the requirements of Wills Act formality. ${ }^{110}$

In 2008, the Uniform Law Commission adopted Professor Langbein's proposal for granting the courts the power to reform an unambiguous will. ${ }^{111}$ The Uniform Probate Code empowers a court to reform an unambiguous will so long as there is clear and convincing evidence (a)

107. Flannery v. McNamara, 738 N.E.2d 739, 746 (Mass. 2000) (internal citations omitted).

108. See, e.g., Langbein \& Waggoner, Reformation of Wills, supra note 4, at 522-23 (explaining the benefits of reforming wills when there is sufficient evidence of intent and arguing that "the time has come for forthright judicial reconsideration of the no-reformation rule.").

109. Id. at 576-77.

110. Langbein, Harmless Errors, supra note 93, at 53 (footnotes omitted).

111. See Unif. Prob. CODE § 2-805 (amended 2019); see also ReSTATEMENT (THIRD) OF PROP.: WILLS AND DONATIVE TRANSFERS $§ 12.1$ (AM. L. INST. 2003). 
that the terms of the will were affected by a mistake, and (b) of the decedent's true intent. ${ }^{112}$ So long as there is clear and convincing evidence of the decedent's true intent, the courts have the power to use extrinsic evidence to reform the will so that it better expresses the testator's testamentary intent. ${ }^{113}$

\section{VII.THE CRUX OF THE DISPUTE}

Despite the nomenclature assigned to the two camps, both the traditional approach and the intent movement agree that testamentary intent is important, and all things being equal, it is better to give effect to a decedent's testamentary intent than not. ${ }^{114}$ The debate is over whether the intent movement's proposals are really an improvement over a more traditional approach to the issues. ${ }^{115}$ Both camps agree that the benefit of

112. Uniform Probate Code $§ 2-805$ states:

The court may reform the terms of a governing instrument, even if unambiguous, to conform the terms to the transferor's intention if it is proved by clear and convincing evidence what the transferor's intention was and that the terms of the governing instrument were affected by a mistake of fact or law, whether in expression or inducement.

UNIF. PROB. CODE § 2-805 (amended 2019). Granting courts the power to reform an unambiguous will is a logical extension of the position first articulated by Gulliver \& Tilson, Classification of Gratuitous Transfers, supra note 9. Relatively early in the article they assert, in surprisingly simple and straightforward phrasing, what one can only assume was a radical statement in light of the traditional, and then prevailing, view of the law of inter vivos and testamentary transfers:

One fundamental proposition is that, under a legal system recognizing the individualistic institution of private property and granting to the owner the power to determine his successors in ownership, the general philosophy of the courts should favor giving effect to an intentional exercise of that power. This is commonplace enough, but it needs constant emphasis, for it may [be] obscured or neglected in inordinate preoccupation with detail or dialectic. A court absorbed in purely doctrinal arguments may lose sight of the important and desirable objective of sanctioning what the transferor wanted to do, even though it is convinced that he wanted to do it.

If this objective is primary, the requirements of execution, which concern only the form of the transfer-what the transferor or others must do to make it legally effective-seem justifiable only as implements for its accomplishment, and should be so interpreted by the courts in these cases. They surely should not be revered as ends in themselves, enthroning formality over frustrated intent.

Id. at 2-3 (emphasis added) (footnote omitted). There it is: an articulation of the formality versus intent tension that is inherent in every Wills Act, and the first scholarly assertion that intent should prevail over formalities. The intent movement has not only adopted that position but extended it to include reforming unambiguous wills to ensure that formality does not frustrate intent.

113. UNIF. PROB. CODE § 2-903 (amended 2019).

114. See infra note 116 and accompanying text.

115. See infra note 117 and accompanying text. 
the intent movement's harmless error and power-to-reform doctrines is that they will result in more wills being probated and more testamentary transfers being given effect. ${ }^{116}$ Where the two camps disagree is with respect to (a) the magnitude of the benefits and (b) the magnitude of the costs associated with the harmless error and power-to-reform doctrines. ${ }^{117}$ Opponents of the harmless error and power-to-reform doctrines are particularly concerned with the increased costs of administration and the increased potential for fraud inherent in both doctrines. ${ }^{118}$

The debate over the cost-benefit analysis of the modern trend doctrines raises difficult questions of how to calculate the values inherent in the analysis. How often are intended wills invalidated under strict compliance? ${ }^{119}$ What is the cost associated with failing to give effect to a decedent's apparent testamentary intent? Is testamentary intent an abstract

116. Glover, A Taxonomy of Intent, supra note 106, at 600-04 (arguing that while harmless error and power-to-reform permit the courts to give greater effect to testamentary intent, they will inherently also introduce greater uncertainty into the respective areas of law because of the subjective, fact sensitive nature of the inquiry and analysis); see also Glover, Minimizing Probate-Error, supra note 13, at 389; Wendel, Flawed Narrative, supra note 7, at 396; Gökalp Y. Gürer, Note, No Paper? No Problem: Ushering in Electronic Wills Through California's "Harmless Error" Provision, 49 U.C. Davis L. Rev. 1955, 1965-66 (2016). But see, Melanie B. Leslie, The Myth of Testamentary Freedom, 38 ARIZ. L. REV. 235, 238, 241 (1996):

[T] here is no reason to believe that the dispensing power and other reforms will result in substantially greater judicial commitment to testamentary intent. Rather, the loosening of formalities will simply lead courts to use different pretexts for imposing their moral order.

Nevertheless, the reformers have sought to minimize both formalities and formalism to increase the effectuation of intent.

Id.

117. See, e.g., Mechem, supra note 64, at 501-02; Glover, Decoupling the Law, supra note 49, at $607-08$.

118. Adam J. Hirsch, Formalizing Gratuitous and Contractual Transfers: A Situational Theory, 91 WASH. U. L. REV. 797, 829 (2014) ("The harmless error power might tend to encourage carelessness and breed litigation, or open up avenues for fraud.") (footnote omitted); see also In re Will of Ranney, 589 A.2d 1339, 1345 (N.J. 1991) ("Our adoption of the doctrine of substantial compliance should not be construed as an invitation either to carelessness or chicanery."). The Court's statement that substantial compliance is not an "invitation" to carelessness is an implicit acknowledgment that it is a likely risk, the question is just how much of a risk. See also, Langbein, Harmless Errors, supra note 93, at 4-5, 37 (acknowledging that one of the principal arguments against the harmless error approach is that it "would invite excessive and difficult litigation.") (footnote omitted).

119. See Glover, Minimizing Probate-Error, supra note 13, at 343 ("Case after case reveals that well-meaning decedents often intend to execute valid wills but fail to comply with the prescribed formalities because of honest mistakes." But no attempt is made to calculate how many-or how often - such intended wills are actually invalidated under strict compliance, as such data is incalculable) (emphasis added) (footnote omitted). 
good that should be valued, in and of itself, the same for all individuals; or does it depend on the value of the property that is being transferred (or not being transferred, as the case may be)? On the other hand, what are the increased costs of administration associated with the harmless error and power-to-reform doctrines? ${ }^{120}$ How much increased fraudulent behavior will there be? ${ }^{121}$ What is the cost associated with giving effect to fraudulent testamentary intent? Is giving effect to fraudulent testamentary intent the same or more costly than failing to give effect to testamentary intent? ${ }^{122}$ How many incidents of fraudulent testamentary intent will go undetected?

The traditionalists tend to (a) discount the marginal benefits associated with harmless error and power-to-reform doctrines, and (b) increase and emphasize the marginal costs associated with the proposals. ${ }^{123}$ The intent advocates, on the other hand, tend to (a) discount the marginal costs associated with these doctrines, ${ }^{124}$ and (b) increase and emphasize the

120. See Kevin Bennardo \& Mark Glover, The Location of Holographic Wills, 97 N.C. L. Rev. 1625,1650 (2019). Professors Bennardo and Glover implicitly recognize that the modern trend intent movement will, at a minimum, increase transaction costs:

Moreover, when it comes to the testator's compliance with external formalities, a presumption of testamentary intent is triggered if the testator complied, or a presumption of the lack of testamentary intent is triggered if the testator failed to comply. These presumptions end the will authentication process in most cases, which in turn limits the costs of litigating the issue of intent.

Id. (footnotes omitted). See also Adam J. Hirsch, Testation and the Mind, 74 WASH. \& LEE L. REV. 285, 296 (2017) ("By calling on courts to judge a testator's volitional state of mind, we would impose on courts an evidentiary burden that raises their decision costs. By barring such evidence, we would lessen those costs."); see also Sherwin, supra note 3, at 469:

There remains a possibility that over a longer period, judicial leniency toward non-standard testamentary transactions might tempt some lawyers to cut corners and some testators to avoid the expense and embarrassment of lawyers. At a minimum, the mystique surrounding wills, which leads most lay people to believe that a will is a solemn transaction in which they should seek legal assistance, could eventually disappear.

Id. (footnote omitted). But see Langbein, Substantial Compliance, supra note 3, 524-26 (arguing that substantial compliance will have little, if any, effect on the amount of probate litigation).

121. Some practitioners assert that academics tend to miscalculate how cheap and easy it is to commit fraud and how hard and expensive it is to prove fraud. See Pamela Bucy Pierson \& Benjamin Patterson Bucy, Trade Fraud: The Wild, New Frontier of White Collar Crime, 19 OR. REv. INT'L L. 1, 8-10 (2018) (commenting on trade fraud); J. Scott Dutcher, Comments and Note, From the Boardroom to the Cellblock: The Justifications for Harsher Punishment of White-Collar and Corporate Crime, 37 ARIZ. ST. L.J. 1295, 1299 (2005) ("[F]raud and other white-collar and corporate crimes are easy to commit and unfortunately hard to detect after the fact.") (footnote omitted).

122. See infra notes 195-97 and accompanying text.

123. See, e.g., Mechem, supra note 64, at 501-02.

124. See Langbein, Harmless Errors, supra note 93, at 51: 
marginal benefits associated with the proposals. ${ }^{125}$

Unfortunately, despite the best efforts of scholars on both sides of the issue, it is impossible to calculate with any certainty the actual costs and benefits associated with the doctrines. Reasonable parties will continue to respectfully disagree for the foreseeable future. Both sides seem to be settling in, with little apparent chance for much movement. That was pretty much my conclusion until two recent developments in California gave me cause to reconsider — and change - my position, sort of.

\section{VIII.THE RECENT CALIFORNIA DEVELOPMENTS}

\section{A. The Caspary Case}

The first development was a recent case out of Northern California, the Caspary case. ${ }^{126}$ The opinion is unpublished, but Professor David Horton eloquently recites the facts in the opening paragraphs of his article, Partial Harmless Error for Wills: Evidence from California, he recites:

Gerard Caspary was born in 1929 in a prosperous Jewish neighborhood in Frankfurt, Germany. When Caspary was four years old, Hitler came to power, and the Caspary family fled to Paris. In 1940, "the Nazis invaded the city." Caspary's parents were sent to Auschwitz, where they were killed. Caspary eluded capture and for three years lived underground in South France.

When the war ended, Caspary immigrated to America. He attended Swarthmore and Harvard, won a Guggenheim Fellowship, and became a beloved medieval history professor at the University of California, Berkeley. Yet as he aged, he increasingly felt compelled to examine his own dark past. Shortly before he retired, he began to teach an undergraduate seminar on the Holocaust. He also wrote a book that combined his childhood memories with translations of his family's

\footnotetext{
A properly conceived harmless error rule actually decreases litigation about Wills Act formalities, although hard cases that require judicial resolution must inevitably arise. A harmless error rule suppresses litigation about technicalities of compliance, since the court will excuse errors anyhow; and the rule subjects whatever litigation still arises to a purposive standard more predictable than the intrinsically arbitrary formalism of the rule of strict compliance.
}

(emphasis added) (footnote omitted).

125. See Langbein \& Waggoner, Reformation of Wills, supra note 4, at 562-64 (discussing the court's hesitation to allow extrinsic evidence to reform the will in Snide v. Johnson (In re Snide), 418 N.E.2d 656 (N.Y. 1981), and refuting the argument that giving courts the power to reform will open the door to "countless fraudulent claims" that are currently barred by the Wills Act).

126. Estate of Caspary, No. RP08396884 (Cal. Super. Ct. filed July 7, 2008). 
wartime letters.

In the spring of 2005, Caspary scheduled a meeting with an estate planner. On May 25, the day before the appointment, Caspary typewrote a one-page document entitled "Last Will." In it, Caspary named two executors and expressed his desire to leave $\$ 10,000$ to his godson, $\$ 5,000$ to his housekeeper, and the "[b]ulk of [his] estate" to the Holocaust Museum in Washington, D.C. However, other portions of the writing seemed tentative, such as the directive that the "[e]xecutors [are] to receive 5\% (?) of [the] estate from the top." In shaky handwriting at the foot of the page, Caspary added his name, address, phone number, and email.

On May 26, Caspary met with the estate planner. Caspary mentioned his experiences in France during the war. He also said that because he was unmarried, childless, and had no close family, he wanted to leave most of his estate to the Holocaust Museum in honor of his parents. After the appointment, the attorney prepared a draft estate plan for Caspary and contacted Caspary several times to set a date to execute it. Despite these attempts, Caspary never responded. On April 6, 2008, Caspary died. ${ }^{127}$

Professor Horton's article supports adoption of the harmless error doctrine, ${ }^{128}$ but even factoring that into his writing, he presents a pretty compelling case. Professor Horton acknowledges that under the traditional, strict compliance approach, "Caspary had failed to make a valid will."129 While Caspary's case was pending, however, California adopted a limited form of the UPC harmless error doctrine. ${ }^{130}$ It had immediate consequences: "A distant relative filed a petition asking the court to admit the May 25 writing to probate. Three of Caspary's friends filed declarations asserting that the typewritten page set forth Caspary's wishes. The case proceeded to trial and then settled, giving the Holocaust Museum a share of the estate." 131

The Caspary case caused me to seriously reconsider my leanings in favor of the traditional approach. Caspary's case highlights the principal argument in favor of the harmless error doctrine: insisting on strict compliance with statutory formalities exalts formalities over intent and leads to "unjust enrichment of unintended" heirs. ${ }^{132}$ One cannot help but

127. David Horton, Partial Harmless Error for Wills: Evidence from California, 103 IowA L. REV. 2027, 2028-31 (2018) (alterations in original) (footnotes omitted).

128. Id. at 2033-34.

129. Id. at 2031 .

130. Id.

131. Id. at 2032 (footnotes omitted)

132. Jane B. Baron, Irresolute Testators, Clear and Convincing Wills Law, 73 WASH. \& LEE L. 
feel that giving Caspary's estate to his distant relatives in Europe, with whom he had little contact, would have been an unjust result. All of the available evidence - Caspary's life experiences in escaping the Holocaust, but losing his parents to it, and the increasing role that experience came to play in his life as he grew older; his teachings and his writings; the fact that he had no family in the United States and he was not close to his relatives back in Europe; and his express statements to friends and his attorney-support the conclusion that, at least at one point in time, his apparent testamentary intent was he wanted to leave the bulk of his estate to the Holocaust Museum in Washington, D.C. and little to nothing to his heirs. ${ }^{133}$ Why he did not return to the attorney's office to execute the will that was prepared for him is a mystery, but his apparent testamentary intent is not. Yet applying strict compliance to his case would contradict all the available evidence concerning his intent, thereby arguably unjustly enriching his heirs.

I confess that one concern I have with the harmless error doctrine is that in at least some of the cases the analysis de facto deteriorates into a probable intent analysis. That is what I found myself doing in the Caspary case. The law provides the court with only two options: intestacy, or his apparent testamentary intent - "apparent" because he failed to execute a valid will. ${ }^{134}$ Presented with only two options, it is natural to ask which one is more likely the decedent's probable intent? Technically, that is not supposed to be relevant under the harmless error doctrine. ${ }^{135}$ The intestate scheme is the default outcome unless there is clear and convincing evidence that the decedent intended the document to be his last will and testament. ${ }^{136}$ That standard, however, is easy to manipulate to support whatever conclusion one reaches. A court can easily reverse engineer an opinion to support the conclusion it favors.

In that sense, one can legitimately ask whether the harmless error doctrine is essentially a step "forward to the past." It harkens back to Professor Bonfield's description of the Prerogative Court of Canterbury and its analysis of medieval wills:

[J]udges in the Prerogative Court [of Canterbury] in the early modern period [the seventeenth century] admitted wills to probate even in

REV. 3, 11 (2016) ("“W]ith respect to Wills Act formalities, it is not clear that courts have authority to deviate from legislatively specified will execution requirements. On the other hand, the strict compliance approach does nothing to further wills law's objective of furthering freedom of disposition. And it allows much unjust enrichment of unintended beneficiaries.") (footnotes omitted).

133. Horton, supra note 127, at 2028-29.

134. See Mann, supra note 42, at 1048-49.

135. See also infra notes 141, 169 and accompanying text.

136. Mann, supra note 42, at 1048-49. 
instances in which it was doubtful that a will conformed to church court law's own minimal due-execution requirements. They did so in the same way as does the modern judge: they created a narrative of what had actually transpired by sifting through the evidence, and then they surmised as to whether the will-maker intended the document to be his or her last will. If they believed that it did, they ignored the defect and proved the will; if they did not, they proclaimed it a nullity. ${ }^{137}$

There is little dispute that the harmless error doctrine, by granting the courts the power to dispense with virtually any and all formalities so long as there is clear and convincing evidence that the decedent intended the document to be his or her will, grants the courts greater discretion over whether a document qualifies as a validly executed will. Moreover, even what constitutes "testamentary intent" is a fungible test. ${ }^{138}$ Does it mean that the decedent intended that piece of paper be taken down and probated as the decedent's last will and testament, or does it simply mean the document, though not intended to be probated as the decedent's last will and testament, adequately expresses the decedent's final wishes with respect to who should get his or her property when he or she dies? ${ }^{139}$

Presented with only two options - intestacy or giving the bulk of Caspary's property to the Holocaust Museum - the equities strongly favor the Holocaust Museum. In light of all the evidence, giving his estate to the Holocaust Museum is more likely his probable intent. This logic, however, worries me. Will the harmless error doctrine "evolve" 140 into a de facto probable intent doctrine? ${ }^{141}$ Moreover, are the harmless error and power-to-reform doctrines nothing more than an attempt to introduce more of a "standards" approach into an area of law that historically has been too

137. Bonfield, DEVISING, Dying AND Dispute, supra note 27, at 133.

138. See generally Baron, supra note 132 (discussing the various ways that courts have interpreted the clear and convincing standard for wills).

139. See generally Glover, A Taxonomy of Intent, supra note 106; Katheleen R. Guzman, Intents and Purposes, 60 U. KAN. L. REV. 305 (2011); David Horton, Wills Without Signatures, 99 B.U. L. REV. 1623, 1640-47 (2019) (arguing that courts should probate an unsigned document so long as the document has "general testamentary intent" (identified the posthumous destination of the party's property) as opposed to requiring "specific testamentary intent" (the decedent intended the document in question to be taken down and probated as the individual's last will and testament)).

140. Or should I say "deteriorate" ... ?

141. There is some evidence that the holographic will doctrine has deteriorated similarly. See generally Zhao v. Wong (In re Estate of Wong), 47 Cal. Rptr. 2d 707, 708-09 (Ct. App. 1995) (where the court held a questionable document did not qualify as a holographic will, after noting the following: "Meanwhile, Xi [the sole beneficiary under the purported apparent will] was having dinner with Brien Wilson at a fancy French restaurant in Los Gatos. She had concealed from Tai [the decedent] the fact that she was dining on New Year's Eve with Brien Wilson, a man she moved in with two and one-half months after Tai's death."). See also Cox v. Towle (In re Estate of Williams), 66 Cal. Rptr. 3d 34 (Ct. App. 2007). 
"law" oriented? ${ }^{142}$ And if so, is that necessarily a bad development?

On the other hand, strict compliance-and the intestate scheme-is not concerned with a decedent's probable intent, nor is it concerned with decedent's actual intent for that matter unless it is properly expressed. ${ }^{143}$ Strict compliance is concerned with the legislature's intent in adopting the Wills Act formalities and applying those formalities to the facts before it. ${ }^{144}$ Under strict compliance, the evidence supporting the argument that Caspary's apparent testamentary intent was to leave the bulk of his estate to the Holocaust Museum to honor his parents is irrelevant. As one who generally favors the traditional strict compliance approach, applying strict compliance in the Caspary case leaves a bad taste in my mouth.

\section{B. The Estate of Duke Case}

If the Caspary case was a body blow to my belief in the traditional approach to how much formality the law should require before giving effect to a testamentary transfer, the California Supreme Court's opinion in Estate of Duke ${ }^{145}$ was a potential knock-out. In 1984, Irving Duke (who was then 72 years old) wrote a holographic will that left all of his estate to his “"beloved wife, Mrs. Beatrice Schecter Duke,' who was then 58 years" old and "[o]ne dollar" to his brother, Harry Duke. ${ }^{146}$ The will went on to provide that, in the event Irving and his wife should die at the same moment:

[M]y estate is to be equally divided-[T] One-half is to be donated to the City of Hope in the name and loving memory of my sister, Mrs. Rose Duke Radin. [I] One-half is to be donated to the Jewish National Fund to plant trees in Israel in the names and loving memory of my mother and father-[đ] Bessie and Isaac Duke. ${ }^{147}$

The will included a standard disinheritance clause. ${ }^{148}$

142. See generally Louis Kaplow, Rules Versus Standards: An Economic Analysis, 42 DUKE L.J. 557 (1992); Pierre J. Schlag, Rules and Standards, 33 UCLA L. REV. 379 (1985).

143. Langbein, Harmless Errors, supra note 93, at 2-5.

144. Id.

145. Radin v. Jewish Nat'l Fund (In re Estate of Duke), 352 P.3d 863 (Cal. 2015).

146. Id. at 865 .

147. Id. (alterations in original).

148. The clause provided:

"I have intentionally omitted all other persons, whether heirs or otherwise, who are not specifically mentioned herein, and I hereby specifically disinherit all persons whomsoever claiming to be, or who may lawfully be determined to be my heirs at law, except as otherwise mentioned in this will. If any heir, devisee or legatee, or any other person or 
Because of the age difference between the two of them, apparently Irving could not conceive of a scenario where Beatrice would predecease him, but in fact that is what happened. Beatrice died in July of 2002. ${ }^{149}$ Irving made no changes to his will following her death. ${ }^{150}$ He died a little over 5 years later, in November of 2007. ${ }^{151}$ Robert and Seymour Radin, the children of Irving's predeceased sister Rose, claimed all of Irving's estate on the grounds that his will failed to address what should happen to his estate if Beatrice predeceased him, so the estate passed through intestacy to them as his only heirs. ${ }^{152}$ The City of Hope and the Jewish National Fund offered extrinsic evidence which they claimed proved that it was Irving's intent that the will would control even in the event Beatrice died before him. ${ }^{153}$ The lower courts refused to consider the extrinsic evidence because there was no ambiguity in the will permitting admission of extrinsic evidence with respect to testamentary intent not expressed in the will. ${ }^{154}$ The trial court granted summary judgment in favor of Robert and Seymour. ${ }^{155}$ The court of appeals affirmed. ${ }^{156}$ The California Supreme Court reversed, ruling that "the categorical bar on reformation of unambiguous wills is not justified and that reformation is permissible if clear and convincing evidence establishes an error in the expression of the testator's intent and establishes the testator's actual specific intent at the time the will was drafted." 157

Although the equities are not quite as strong as they are in the Caspary case, the equities of the Duke case again had me reconsidering my longstanding preference for the more traditional approach to how much formality the law should require before giving effect to a testamentary transfer. Irving had handwritten his will, clearly expressing his intent that he did not want any family members other than his wife to take his estate. ${ }^{158}$ He left his brother Harry the token gift of "[o]ne dollar," no doubt to indicate that his failure to provide for his brother was not an

persons, shall either directly or indirectly, seek to invalidate this will, or any part thereof, then I hereby give and bequeath to such person or persons the sum of one dollar $(\$ 1.00)$ and no more, in lieu of any other share or interest in my estate."

Id. at $865-66$.

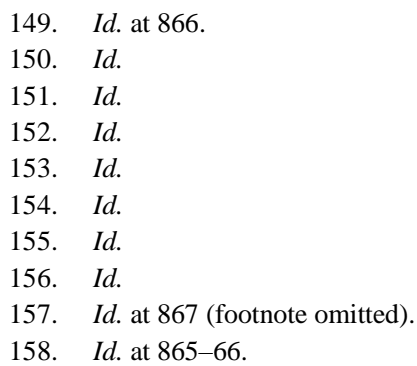


oversight. ${ }^{159}$ He included a standard disinheritance clause with respect to any and all other heirs who might assert a claim. ${ }^{160}$ His primary intent was to care for his wife, but in the event that was not necessary (if they died together), he wanted his estate to go to charity to honor his parents. ${ }^{161}$

As applied to the facts of the Duke case, insisting on application of the traditional approach to when extrinsic evidence is admissible to help "construe" a will-to help give effect to testamentary gifts that are 'poorly" drafted-would arguably exalt form over substance, formalities over intent, and lead to unjust enrichment of unintended heirs. ${ }^{162}$ All the available evidence supports the conclusion that Irving considered his family situation when writing his will and concluded that the only person he wished to leave any meaningful gift to was his "beloved wife" Beatrice, and in the event that was not possible, he wanted to honor his parents by leaving it to charity. ${ }^{163}$ Giving Irving's estate to Robert and Seymour Radin would contradict all the available evidence concerning Irving's testamentary intent, thereby arguably unjustly enriching his heirs. ${ }^{164}$

The California Supreme Court concluded that no sound reason exists to forbid the reformation of unambiguous wills where the evidence justifies it. ${ }^{165}$ While not directly connecting the issue to the harmless error provision that the California legislature had recently adopted, the court implicitly connected the issues by discussing how the statute of wills and the statute of frauds both set forth formalities that should be satisfied before the writing is valid, but that the law has created exceptions to both statutes where there is clear and convincing evidence. ${ }^{166}$ Embracing Professor Langbein's logic, the California Supreme Court concluded that the clear and convincing evidence civil standard provides sufficient safeguards to adopt the modern trend, intent-based power-to-reform doctrine. ${ }^{167}$

The equities of the Caspary case and the Duke case are strong. Both involve a loving child whose testamentary wish is to honor his parents, and such intent would be frustrated by the traditional approach to how much formality the law should require before giving effect to a will or

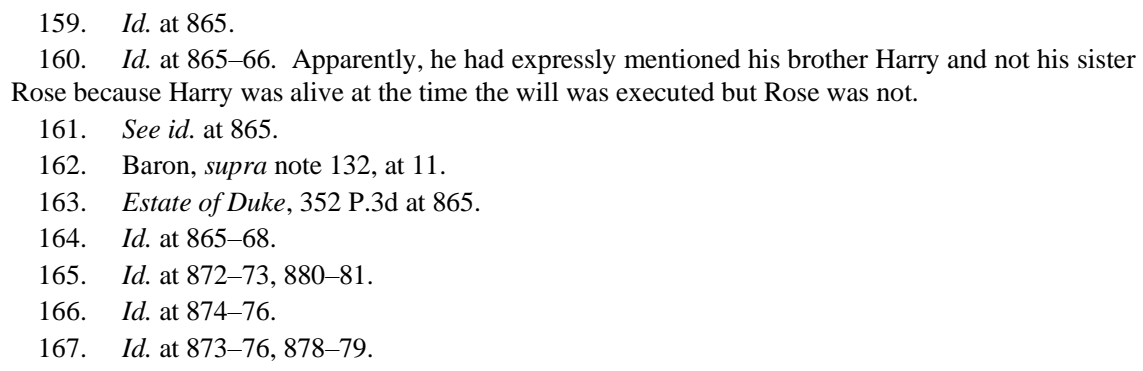


testamentary transfer via a will. ${ }^{168}$ In both cases, the court had only two options, and while technically the law says it should favor one unless there is clear and convincing evidence that the other is the decedent's intent, in both cases it is natural to ask which one is more likely the decedent's probable intent. ${ }^{169}$ Is that, de facto, what the intent movement is all about, and if so, is that really so bad?

As I struggled with the arguments on both sides of the debate, it dawned on me, if one pulls the lens back a bit, there is a common thread that connects both the Caspary and Duke cases. In both cases, the intended gift that would have been frustrated if the court had applied the traditional approach was a philanthropic gift; a charitable gift. ${ }^{170}$ Might it be that the charitable nature of the gift in question is what justifies-if anything does-adopting the modern trend intent oriented approach?

\section{The SPeCIAL LEGAL TREATMENT ACCORDED PHILANTHROPY}

While it is generally accepted that testamentary intent is a social good that should be given effect whenever possible, it is even more generally accepted that philanthropy is a social good that should be encouraged and facilitated whenever possible. "The implicit rationale runs like this: charitable organizations, charitable donors, and the government are all in the business of benefitting the public. It makes sense, then, for the government to help charities and their donors do their good works . . .."171

168. Horton, supra note 127, at 2029; Estate of Duke, 352 P.3d at 865.

169. Technically, probable intent is only supposed to be relevant for construction purposes, not validity purposes, but one can easily imagine courts have a hard time holding that line. See In re Will of Smith, 528 A.2d 918, 922 (N.J. 1987), where the New Jersey Supreme Court noted "the doctrine of probable intent is available only to interpret, but not to validate, a will. [The doctrine] comes into play only after a will is found to be valid" (internal citations omitted). But the fact that the Court had to admonish the lower court implicitly acknowledges that some courts blur the line. Id. This potential is even greater in holographic will scenarios. See generally Cox v. Towle (In re Estate of Williams), 66 Cal. Rptr. 3d 34 (Ct. App. 2007); Zhao v. Wong (In re Estate of Wong), 47 Cal. Rptr. 2d 707, 70910, 712-13 (Ct. App. 1995); and supra note 141 and accompanying text. The will reformation doctrine is little more than probable intent; it goes to will construction, not validity. See, e.g., Jeffrey Daniel Haskell, When Axiom Collide, 15 CARDOZO L. REV. 817, 830 (1993). Inasmuch as New Jersey is the state that pioneered the probable intent doctrine, see Reid Kress Weisbord \& David Horton, Boilerplate and Default Rules in Wills: An Empirical Analysis, 103 IOWA L. REV. 663, 687-88 (2018). Is the New Jersey Supreme Court's admonishment in Will of Smith a harbinger of things to come if the reformation doctrine is widely adopted? See also Adam J. Hirsch, Text and Time: A Theory of Testamentary Obsolescence, 86 WASH. U. L. REV. 609, 645 (2009) (acknowledging that probable intent is already relevant to the doctrine of implied revocation). Inasmuch as probable intent is already used for revocation purposes, and will revocation is the flip side of will execution, will the courts really hold the construction/validity line?

170. Horton, supra note 127, at 2029; Estate of Duke, 352 P.3d at 866.

171. Rob Atkinson, Tax Favors for Philanthropy: Should Our Republic Underwrite de Tocqueville's Democracy?, 6 WM. \& MARY POL'Y REV. 1, 9 (2014) (emphasis added); see also John 
Governmental support for charitable activities, and charitable contributions, has existed for centuries and is nearly universal. ${ }^{172}$ Charities existed and were granted special status during the times of the pharaohs in early Egypt, and during early Roman and Greek periods. ${ }^{173}$ Most countries embrace the assumption that charitable activities are a good and should be encouraged. ${ }^{174}$ Countries encourage and support charitable activities in a plethora of ways, all of which involve special treatment under the law. ${ }^{175}$

The special legal treatment accorded charitable organizations evidences how far the law will go to encourage and support organizations that engage in charitable work that benefits the public:

Once an organization has been granted exempt status under $\S$ 501(c)(3) it will receive significant government benefits, predominantly in the form of special tax treatment. The privilege of receiving taxdeductible contributions for income, estate, and gift tax purposes is perhaps the most well-known benefit. However, in addition to this benefit, charitable organizations may qualify to issue tax-exempt bonds, avoid federal unemployment taxes, and provide tax-deferred retirement plans for their employees. In addition to federal tax benefits, charitable organizations are generally eligible to receive tax benefits at the state level, although the benefits vary by jurisdiction. Alongside the many tax benefits are nontax benefits such as preferred postage rates and potential exemptions from regulatory regimes such as antitrust, securities, labor, and bankruptcy. ${ }^{176}$

Charitable trusts is another area of law where a number of special rules have been developed to facilitate and perpetuate charitable gifts. ${ }^{177}$

A. Pearce II, The Rights of Shareholders in Authorizing Corporate Philanthropy, 60 VILL. L. REV. 251, 254 (2015) ("The United States government supports corporate philanthropy through its tax policy.") (footnote omitted). But see Elizabeth R. Carter, Tipping the Scales in Favor of Charitable Bequests: A Critique, 34 PACE L. REV. 983, 983-84 (2014) (acknowledging that "[p]ublic policy favors testamentary bequests to charity" but arguing "that the policy favoring charitable giving has gone too far.").

172. Patton, supra note 39 at 134; Carter, supra note 171, at 1002-12; Susan N. Gary, Restricted Charitable Gifts: Public Benefit, Public Voice, 81 AlB. L. Rev. 565, 570 (2018) (“[T]he idea that charities and charitable trusts have a public purpose goes back centuries.").

173. Patton, supra note 39 at 134; Carter, supra note 171, at 1002-12.

174. Patton, supra note 39 at 134; Carter, supra note 171, at 1002-12. See also, Susan Pace Hamill, An Evaluation of Federal Tax Policy Based on Judeo-Christian Ethics, 25 VA. TAX REV. 671, 703-10 (2006).

175. Patton, supra note 39 at 134; Carter, supra note 171, at 1002-12.

176. Tiffany Keb, Comment, Redefining What it Means to Be Charitable: Raising the Bar with a Public Benefit Requirement, 86 OR. L. REv. 865, 870 (2007) (footnotes omitted); see also Gary, supra note 172, at 570 ("The idea that charity provides a public benefit can be seen throughout the history of charities law in England."); Carter, supra note 171, at 1016-17.

177. See generally Mark A. Barwise, The Modern Charitable Trust, 9 ME. L. REv. 225 (1916) (discussing the history of the legal treatment of charitable trusts); Craig Kaufman, Sympathy for the Devil's Advocate: Assisting the Attorney General When Charitable Matters Reach the Courtroom, 40 
Charitable trusts are exempt from the private trust requirement that there be identifiable beneficiaries who have standing to sue the trustee to enforce the terms of the trust. ${ }^{178}$ Moreover, charitable trusts are not subject to the Rule Against Perpetuities. ${ }^{179}$ Permitting perpetual trusts and trusts with no ascertainable beneficiaries increase trust administration issues down the road, thereby increasing costs of administration for society. ${ }^{180}$ Nevertheless, the law accepts such costs because of the offsetting benefits to society: "The courts have refused to apply any rule limiting the duration of trusts to charitable trusts because they have felt that the social advantages of such trusts more than offset the disadvantages ...."181 The cost-benefit analysis associated with charitable gifts is different from the cost-benefit associated with non-charitable gifts because of the public benefit associated with charitable gifts.

Arguably the best example of how far the law is willing to go to take advantage of the benefits associated with charitable gifts is the cy pres doctrine. The cy pres doctrine traces its roots back to the English courts

REAL PROP. PROB. \& TR. J. 705, 710-11 (2006):

Modern charitable trust law has its roots in England because the charitable trust is an invention of the English judiciary, enforceable in equity. Indeed, because the charitable trust is a favored creation of the law enjoying the exceptional attentiveness of courts of equity, a liberal interpretation is often employed to uphold this type of trust.

(emphasis added) (footnotes omitted).

178. George Gleason Bogert, George Taylor Bogert, Amy Morris Hess, Norman M. ABRAMSON \& SUSAN GARY, BOGERT's THE LAW OF TRUSTS AND TRUSTEES $§ 323$ (last updated June 2020) ("A private trust must have an identifiable beneficiary or beneficiaries, but this requirement does not apply to the creation of a charitable trust.") (footnote omitted). See also, Verner F. Chaffin, Georgia's Proposed Dynasty Trust: Giving the Dead Too Much Control?, 35 GA. L. REV. 1, 12 (2000) ("a charitable trust need not have identifiable beneficiaries") (footnote omitted); Mosk v. United Cal. Bank (In re Estate of McKenzie), 38 Cal. Rptr. 496, 497-98 (Dist. Ct. App. 1964).

179. RESTATEMENT (SECOND) OF TRUSTS $\$ 365$ (AM. L. INST. 1959); BOGERT ET AL., supra note 178, § 351; RESTATEMENT (THIRD) OF TRUSTS $§ 28$, cmt. d (AM. L. INST. 2003); RESTATEMENT (THIRD) OF PROPERTY WiLlS AND DONATIVE TRANSFERS $§ 27.3(2)$ (AM. L. INST. 2003).

180. Gary, supra note 172, at 573 ("The lack of a beneficiary with the power and incentive to enforce the trust, creates a problem for oversight and enforcement.") (footnote omitted); see also Susan N. Gary, Regulating the Management of Charities: Trust Law, Corporate Law, and Tax Law, 21 U. Haw. L. Rev. 593, 596 (1999); Geoffrey A. Manne, Agency Costs and the Oversight of Charitable Organizations, 1999 WIS. L. REV. 227 (1999); Alberto B. Lopez, A Revaluation of Cy Pres Redux, 78 U. CIN. L. REV. 1307, 1321 (2010) ("To make the most of the charitable dollar in trust, courts must have the power to modify the charitable trust to prevent that dollar from being wasted on outmoded charitable initiatives.").

181. BOGERT ET AL., supra note 178, § 351, n.6 ("The public policy reason that charitable trusts should be treated differently than private trusts with respect to the applicability of I.C. $§ 55-111$ is the great benefit to society arising from charitable trusts.") (citing In re Coleman's Estate, 138 P. 992 (Cal. 1914)); see also Storr's Agricultural School v. Whitney, 8 A. 141, 143 (Conn. 1887) ("The law favors charitable uses. It does so with knowledge that in most cases they are intended to be practically perpetual; and it is willing to permit what of evil results from the devotion of property to such length of use in consideration of the beneficent results flowing therefrom."). 
of equity. ${ }^{182}$ The courts of equity bent, ignored, and/or created law in pursuit of giving maximum effect to charitable gifts and charitable activities:

[I]nstitutions that devoted their properties to one or more . . charitable uses or that had property entrusted to them for ... charitable uses received a variety of equitable privileges. Special trust and testamentary doctrines, like the cy pres doctrine, enabled the institutions to receive property by deeds and wills that were defective in form and generally unenforceable at common law. Special property rules enabled them to transfer goods and lands to beneficiaries, free from liens, fees, and excises. Special procedural rules allowed them to bring actions that were otherwise barred by the statute of limitations or by the doctrine of laches. Special tax rules afforded them both tax subsidies and tax exemptions. These charitable institutions received subsidies from the "poor rates," "education rates," and "charity taxes" that the authorities occasionally levied on the community. They received exemptions from taxes on those portions of their property that were "devoted to charitable uses and other public concernments." 183

The cy pres doctrine evidences how far the law will bend to give effect to charitable intent. Cy pres saves an otherwise failing charitable gift, often at the expense of the donor's heirs:

Although legal historians dispute the origins of the term, the principle of cy pres can be traced back at least as far as the sixth-century Roman Empire. The close relation between law and religion during the Middle Ages, especially at the time of death, likely gave rise to cy pres in English law. In medieval England, the deceased's estate was commonly divided, with one third ("the dead's part") applied by the administrators "for the good of his soul in such pious works as they shall think best according to God and good conscience." The courts recognized that the public benefit of charitable acts, and the value to the testator's soul, would be lost if such charitable donations reverted to the heirs when the gift intended could not be completed. To avoid this outcome, the courts would rededicate the gift to an alternative use in line with the donor's intentions. These early principles of cy pres were adopted and codified in the Statute of Charitable Uses, a broad statute with "such medicinal qualities in it, as to heal every imperfection in a charitable disposition, provided the party had a legal capacity to give at all."184

While the conventional wisdom is that cy pres is an intent saving

182. Barwise, supra note 177 , at 230-31.

183. John Witte Jr., Tax Exemption of Church Property: Historical Anomaly or Valid Constitutional Practice?, 64 S. CAL. L. REv. 363, 377 (1991) (emphasis added) (footnotes omitted).

184. Chris J. Chasin, Modernizing Class Action Cy Pres through Democratic Inputs: A Return to Cy Pres Comme Possible, 163 U. PA. L. REV. 1463, 1465-66 (2015) (footnotes omitted) (emphasis added). 
doctrine, which implies it is a pro-intent doctrine, it needs to be remembered that the intent is only worth saving because of the public benefits associated with it because of the charitable gift it saves.

Another source of confusion concerning the cy pres doctrine as it was introduced to the American courts lies in the overemphasis placed upon the effectuation of the donor's intent. It appears quite certain that the doctrine did not originate solely as an intent-enforcing device. It has been suggested that the actual origin of cy pres is to be found in the civil law.

There are Roman cases wherein memorial gifts for specified purposes were, when found illegal, applied to proper objectives in order that the memory of the donor might be preserved. There seems to be as much emphasis upon the social benefit to be derived from such gifts as on any desire to effectuate the donor's intention. The rationale of these cases is that it would be unjust for a gift destined for charitable ends to fall back to the heirs because of some technical difficulty.... In origin, then, it would appear that cy pres was employed chiefly with the aim of advancing purposes believed to be of great social benefit. Gradually, however, this emphasis changed; judicial cy pres tended more and more to become a rule of construction and solely an intent-enforcing instrument.

$\cdots$

In these three types of cases there seems no sound reason for denying validity. The social desirability of maintaining these donations in charitable channels is conceded. The donor has shown his intent to devote the fund to charitable purposes rather than to his heirs. ${ }^{185}$

For centuries the courts of equity have used cy pres to give effect to charitable intent that otherwise would fail. ${ }^{186}$ While the effect of the doctrine has been to promote the donor's intent, technically the rationale underlying the doctrine is not the donor's intent per se but rather the public benefits associated with the charitable intent. ${ }^{187}$

185. A Revaluation of Cy Pres, 49 YALE L. J. 303, 309-10, 313 (1939) (footnotes omitted) (emphasis added); see also Kaufman, supra note 177, at 714 ("Permitting judicial action to remodel the trust preserves the public benefits of charitable trusts ....") (emphasis added).

186. A Revaluation of Cy Pres, supra note 185, at 311.

187. Chasin, supra note 184, at 1465-66. At early common law, there were two forms of cy pres: prerogative cy pres and judicial cy pres. A Revaluation of Cy Pres, supra note 185, at 303-06; Lopez, supra note 180, at 1313. Judicial cy pres saved an ineffective charitable gift by invoking the court's equitable powers to save it for another purpose as close as possible to the donor's original charitable objective. Id. at 1314. On the other hand, prerogative cy pres was a "power of the Crown," the court was merely the agent which implemented the Crown's power. Id. at 1313-17. Prerogative cy pres saved an otherwise failing charitable gift for whatever specific charitable purpose the Crown deemed appropriate, regardless of the donor's original charitable objective. $I d$. While judicial cy pres arguably 
Circling back to the Caspary and Duke cases, is it solely the "testator's intent" that is driving the equities and analysis of those cases, or is the distinguishing variable the fact that in both cases the gift otherwise would have gone to charities that would have put the gift to public good? To the extent the testamentary intent movement seeks to lower the legal bar that is required before giving effect to a testamentary gift, the normative case for such change in the law can be made much easier with respect to charitable testamentary gifts than non-charitable testamentary gifts. Charitable testamentary gifts are for the public good, so the benefits of giving effect to such gifts - either through the harmless error doctrine or the power to reform-on average will exceed the costs. ${ }^{188}$ Testamentary gifts differ from inter vivos gifts because of the finality of the attempted testamentary transfers. Invalidating an attempted inter vivos charitable transfer presumedly has little cost because if the transferor still has the same intent, he or she can simply re-execute the transfer to correct the mistake. ${ }^{189}$ Invalidating an attempted testamentary charitable transfer carries greater costs with it because of the finality inherent in testamentary gifts. The donor does not have a chance to cure the defect. In such

is more of a rule of construction, prerogative cy pres is more of a curative doctrine. See, e.g., Chasin, supra note 184 , at $1466-67$. In both scenarios, however:

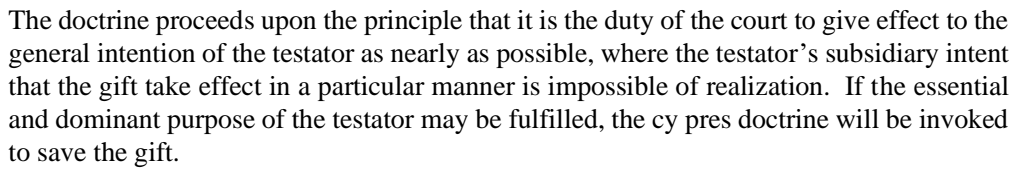
general intention of the testator as nearly as possible, where the testator's subsidiary intent that the gift take effect in a particular manner is impossible of realization. If the essential and dominant purpose of the testator may be fulfilled, the cy pres doctrine will be invoked to save the gift.

Anne E. Melley, 18 N.Y. JuR. 2D ChaRITIES $§ 45$ (2020) (footnotes omitted). Cy pres has had a mixed history in America because of the controversial nature of prerogative cy pres and England's failure to delineate when the different versions of cy pres applied. Lopez, supra note 180, at 1319-25. Not all states recognize cy pres, and those that do tend to recognize judicial cy pres, but not prerogative cy pres. See A Revaluation of Cy Pres, supra note 185, at 307-08. The driving force behind the doctrine of cy pres, however, is, consistent with the donor's intent, ensuring use of the property for the public good. Id. at 313 .

188. See supra notes $171-85$, and accompanying text.

189. Some have argued that where a donor expresses the intent to make an inter vivos gift but dies unexpectedly before delivering the item, the courts should save the gift by (1) recharacterizing the intent to make an outright gift as a declaration of trust, (2) appointing a successor trustee, and (3) ordering the new trustee to deliver the intended gift item to the donee. Understandably, there has been criticism of such a remedy because (a) the donor did not have the intent to create a trust so recharacterizing the donor's intent is a sham; and (b) the cost-benefit analysis in question. The Restatement (Third) of Trusts rejects this approach. See RESTATEMENT (THIRD) OF TRUSTS § 16(2) (AM. L. INST. 2003). The comments to the section walk back the official position a bit. See id. at cmt. d. The Restatement (Third) of Property moots the issue by eliminating the traditional requirement that the item being gifted must be delivered. See Restatement (THIRD) OF PROP.: WiLls AND DONATIVE TRANSFERS $§ 6.2 \mathrm{cmt}$. yy (AM. L. INST. 2003). Limiting the elimination of the delivery requirement to failed inter vivos charitable gifts where the donor dies before having a chance to remedy the mistake is more defensible both doctrinally and from a public policy perspective. 
circumstances, both as a doctrinal matter and as a matter of public policy, it makes sense to adopt the modern trend intent approach as set forth in the harmless error and the power to reform doctrines to save the otherwise failing testamentary charitable gift. ${ }^{190}$

\section{CONCLUSION}

In his article Defective Catastrophe Clauses in Wills: Paths to Reform, Professor Adam Hirsch takes the California Supreme Court to task for its opinion in Duke. ${ }^{191}$ His assessment of the Court's opinion is reflected in the heading of the section which analyzes the opinion: "The Duke Debacle." ${ }^{192}$ Professor Hirsch criticizes the Court for adopting a remedy that is "ill-fitted to the facts of the case." 193

190. A latent issue not raised directly by either the Caspary or Duke case is how the courts should treat a will that includes one or more charitable gifts, as well as a number of noncharitable gifts. Erring on the side of encouraging and facilitating charitable gifts, as the law has historically done, the intent oriented harmless error doctrine should apply to any will that includes at least one meaningful (i.e., non-sham) charitable gift. The situation is analogous to charitable split-interest trusts. Charitable split-interest trusts (i.e., deferred gifts and charitable remainder trusts in particular) are excellent examples of where the law permits mixed charitable and noncharitable gifts and accords special treatment to such trusts (significant estate, gift, and income tax benefits) to promote and facilitate charitable gifts. See generally Gregory L. Prescott \& James R. Hardin, Charitable Remainder Trusts: A Popular and Effective Estate Planning Tool, 98 PRAC. TAX. STRATEGIES 183 (2017); Christopher R. Hoyt, Transfers from Retirement Plans to Charities and Charitable Remainder Trusts: Laws, Issues and Opportunities, 13 VA. TAX REV. 641, 669-702 (1994) (As of 1991, there were "over 36,000 charitable remainder trusts that [held] over $\$ 8$ billion of assets"). Inasmuch as the power to reform is gift specific, not document specific, no such latent issues arise with respect to extending it to failed testamentary charitable gifts but not to failed testamentary noncharitable gifts.

191. Adam J. Hirsch, Defective Catastrophe Clauses in Wills: Paths to Reform, 52 Real PROP. TRust \& Estate L. J. 339, 341-50 (2018) [hereinafter, Hirsch, Destructive Catastrophe Clauses].

192. Id. at 341 .

193. Id. at 345. His analysis starts with the California Supreme Court's articulation of the power to reform: "an unambiguous will may be reformed if clear and convincing evidence establishes that the will contains a mistake in the expression of the testator's intent at the time the will was drafted and also establishes the testator's actual specific intent at the time the will was drafted." Id. (quoting Estate of Duke, 352 P.3d at 865.). That gives rise to the question of what constitutes a "mistake in the expression." Professor Hirsch shows how that phrase, "mistake in expression," is a term of art. Hirsch, Destructive Catastrophe Clauses, supra note 191, at 343-45. As that term has been used historically and currently, the heirs in the Estate of Duke case should have a difficult time carrying their burden of proof. Id. at 345-47. Prof. Hirsch goes on to criticize the Court for apparently conflating two very different types of drafting mistakes:

The court in Duke collapsed inartful expression with clerical error as characteristics of a will eligible for reformation. In other words, the court asserted a power to correct wills that not only fail to say what they are supposed to say, but also appear not to mean what they are supposed to mean.

Id. at 346 (emphasis in original). Professor Hirsch notes that extrinsic evidence with respect to meaning typically will come "from third parties who might or might not be interested," implicitly 
While I agree with Professor Hirsch that the California Supreme Court's opinion in the Duke case is a debacle that is ill-fitted for the facts, I respectfully submit that the reason for the debacle is the Court failed to address the elephant in the opinion: the charitable nature of the testamentary gift. There is a long and rich history of the law according special status to charitable gifts. ${ }^{194}$ The charitable nature of the testamentary gift in the Duke case is the "good cause" that justifies adopting and applying the power-to-reform doctrine. ${ }^{195}$

Professor Hirsch wraps up his analysis of the Duke case by stating that not all legal errors are of equal cost: "To be sure, an evaluation that some legal errors are more costly than others is perfectly plausible and sometimes justifiable." 196 He notes that "the English treatise writer Charles Fearne paraphrased Blackstone," asserting that giving effect to fraudulent testamentary intent would be worse than convicting an innocent man:

In defense of the traditional rules of will construction excluding extrinsic evidence altogether, Fearne averred that "it is better that the intentions of twenty testators, every week, should fail of effect, than those rules should be departed from, upon which the general security of titles and quiet enjoyment of property so essentially depend." 197

With respect to Fearne's assertion that not all failed gifts are equal, Professor Hirsch commented that "the rationale for favoring one category of beneficiary over another would demand analysis." 198

With respect to favoring intended beneficiaries of failed charitable testamentary gifts, the analysis is obvious. Granting preferential treatment to failed charitable testamentary gifts is not only logical and defensible, it is consistent with the longstanding and widespread legal tradition of according favorable treatment to charitable gifts. The Duke and Caspary cases, viewed properly as failed charitable testamentary gift cases, evidence the merit of according such failed gifts special treatment.

\footnotetext{
acknowledging that the California Supreme Court's power to reform doctrine will significantly increase costs of administration and the potential for fraud. Id. Professor Hirsch wraps up his analysis with a rather interesting comment: "Whether the court in Duke understood what it was doing — whether this was all just pretense in a good cause-remains unclear." Id. at 348. Apparently by "all just pretense in a good cause" Prof. Hirsch was referring to the modern trend intent movement; that giving more effect to testamentary intent is a good cause.

194. See supra notes 171-187, and accompanying text.

195. Hirsch, Destructive Catastrophe Clauses, supra note 191, at 348.

196. Id. at 349

197. Id. at 349-350 (quoting 1 CHARLES FEARNE, AN ESSAY ON THE LEARNING OF CONTINGENT REMAINDERS AND EXECUTORY DEVISES 172-73 (Charles Butler \& Josiah W. Smith eds., 10th ed.1845)) (footnote omitted).
}

198. Id. at 350 (footnote omitted). 
Because of the public benefits inherent in charitable gifts, the cost-benefit analysis of applying the harmless error and/or the power-to-reform doctrines to failed charitable testamentary gifts makes sense and is good public policy. Where the failed testamentary gift is a charitable gift, the traditionalists should find common ground with the intent-oriented advocates.

Removing failed charitable testamentary gifts from the universe of failed testamentary gifts ${ }^{199}$ also reframes the issue of whether the harmless error and/or power-to-reform doctrines should apply to the remaining cases. Assume, arguendo, that the failed gift in Duke had been to a friend, not a charity. In light of the fact that Irving Duke, a multi-millionaire, did not care enough about his testamentary intent to go to an attorney to ensure that the gift was properly expressed, why should the state spend thousands of dollars to ascertain and give effect to his non-charitable testamentary intent? Where the failed testamentary gift is a noncharitable gift, should limited public resources be spent trying to ascertain and give effect to the decedent's intent? Would it be better to spend those limited public resources on other, more pressing social problems? $?^{200}$ Where the failed testamentary gift is a noncharitable gift, the absence of public benefits makes the cost-benefit analysis of adopting and applying the harmless error and/or the power-to-reform doctrines to the failed gift more difficult.

Let the debate begin anew.

199. Removing them because it is assumed, arguendo, that it makes sense to apply the harmless error and/or the power-to-reform doctrines.

200. See Wendel, Flawed Narrative, supra note 7, at 387.

With the myriad of competing claims on public resources, it is poor public policy to spend excessive public funds on ascertaining testator's intent when imposing reasonable formalities on testators, reasonably interpreted and reasonably applied, can save society money and permit society to allocate its scarce resources to more pressing needs.

Id. 